OPEN ACCESS

Edited by:

Karine Rizzoti,

Francis Crick Institute,

United Kingdom

Reviewed by:

Leonard Cheung,

University of Michigan, United States

Teddy Fauquier,

Aix-Marseille Université, France

*Correspondence:

Hugo Vankelecom

hugo.vankelecom@kuleuven.be

Specialty section:

This article was submitted to

Neuroendocrine Science,

a section of the journal

Frontiers in Endocrinology

Received: 09 September 2020

Accepted: 25 November 2020

Published: 29 January 2021

Citation:

Laporte E, Vennekens A and

Vankelecom H (2021) Pituitary

Remodeling Throughout Life: Are

Resident Stem Cells Involved?

Front. Endocrinol. 11:604519.

doi: 10.3389/fendo.2020.604519

\section{Pituitary Remodeling Throughout Life: Are Resident Stem Cells Involved?}

\author{
Emma Laporte, Annelies Vennekens and Hugo Vankelecom* \\ Laboratory of Tissue Plasticity in Health and Disease, Cluster of Stem Cell and Developmental Biology, Department of \\ Development and Regeneration, KU Leuven (University of Leuven), Leuven, Belgium
}

The pituitary gland has the primordial ability to dynamically adapt its cell composition to changing hormonal needs of the organism throughout life. During the first weeks after birth, an impressive growth and maturation phase is occurring in the gland during which the distinct hormonal cell populations expand. During pubertal growth and development, growth hormone $(\mathrm{GH})$ levels need to peak which requires an adaptive enterprise in the $\mathrm{GH}$-producing somatotrope population. At aging, pituitary function wanes which is associated with organismal decay including the somatopause in which GH levels drop. In addition to these key time points of life, the pituitary's endocrine cell landscape plastically adapts during specific (patho-)physiological conditions such as lactation (need for PRL) and stress (engagement of $\mathrm{ACTH}$ ). Particular resilience is witnessed after physical injury in the (murine) gland, culminating in regeneration of destroyed cell populations. In many other tissues, adaptive and regenerative processes involve the local stem cells. Over the last 15 years, evidence has accumulated that the pituitary gland houses a resident stem cell compartment. Recent studies propose their involvement in at least some of the cell remodeling processes that occur in the postnatal pituitary but support is still fragmentary and not unequivocal. Many questions remain unsolved such as whether the stem cells are key players in the vivid neonatal growth phase and whether the decline in pituitary function at old age is associated with decreased stem cell fitness. Furthermore, the underlying molecular mechanisms of pituitary plasticity, in particular the stem cell-linked ones, are still largely unknown. Pituitary research heavily relies on transgenic in vivo mouse models. While having proven their value, answers to pituitary stem cell-focused questions may more diligently come from a novel powerful in vitro research model, termed organoids, which grow from pituitary stem cells and recapitulate stem cell phenotype and activation status. In this review, we describe pituitary plasticity conditions and summarize what is known on the involvement and phenotype of pituitary stem cells during these pituitary remodeling events.

Keywords: pituitary, plasticity, stem cells, organoids, regeneration, maturation, aging 


\section{INTRODUCTION}

One of the defining characteristics of the pituitary gland is its ability to plastically adapt its cell composition to fulfill changing endocrine demands of the body throughout life. The gland occupies a central position in the endocrine system, upstream receiving regulatory signals from the hypothalamus and downstream sending hormonal messages to endocrine organs throughout the body (such as adrenal and thyroid glands, ovaries and testes), thereby regulating the production of specific hormones by these target glands. Tight control of pituitary hormonal release is maintained via a strict balance between cues from the hypothalamus and negative feedback loops from the peripheral target hormones. The major endocrine part of the gland (i.e., anterior pituitary, AP) contains five endocrine cell types, each dedicated to produce (a) specific hormone(s). Somatotropes synthesize and secrete growth hormone $(\mathrm{GH})$, generally involved in bone and organ growth and regeneration; lactotropes produce prolactin (PRL), playing an essential role in pregnancy and lactation; gonadotropes generate follicle stimulating hormone (FSH) and luteinizing hormone (LH), controlling fertility and reproduction; adrenocorticotropic hormone $(\mathrm{ACTH})$ is produced by corticotropes and necessary in stress and immune responses; and thyrotropes make thyroidstimulating hormone (TSH) which is indispensable in metabolism control $(1,2)$. Apart from these endocrine cells, the AP also houses non-hormonal cell types encompassing endothelial, immune, and folliculostellate (FS) cells. Existence of stem cells in the pituitary gland was theorized for many decades until their convincing disclosure 15 years ago and thorough description since then, along with the identification of a number of stem cell markers, positioning SOX2 at the head of the list (3-7). From the multiple studies set out to unveil the biological significance of this stem cell population, it is at present perceived that these cells, at least in the basal adult gland, are highly quiescent. Thorough insight into their function(s) is still not firmly achieved $(2,8)$.

During postnatal life, several physiological processes ask for adaptations in hormone balances and thus pituitary output. The gland shows the essential flexibility to alter hormonal production by remodeling its function and cellular composition in these conditions. For onset and development of puberty, GH and gonadotropins ( $\mathrm{LH}$ and $\mathrm{FSH}$ ) are needed to drive and regulate pubertal growth spurt and gonad maturation (through the sex steroid hormones testosterone and estradiol), respectively (9). Increased levels of PRL are needed during pregnancy and lactation [to enlarge and prepare mammary glands for milk production (10-12)], and elevated ACTH concentrations are necessary to cope with stress (13-15). Pituitary cell remodeling is also seen in early-postnatal life, when the (rodent) pituitary gland undergoes prominent growth and maturation $(2,16,17)$. In contrast, remodeling capacity may be compromised at aging concurrent with pituitary functional decline (18). Finally, injury in the gland during postnatal life triggers a local regenerative remodeling process culminating in regeneration of tissue cells and hormonal function (19-22). In general, it is only poorly understood how the specific cellular changes during these remodeling events are brought about, and whether and how pituitary stem cells are involved.

In this review, we summarize dynamic adaptations in the pituitary cell landscape at key time points of postnatal life and during specific (patho-)physiological processes, and discuss the current knowledge regarding involvement of the resident stem cells in these remodeling processes. To gain deeper insight into stem cell phenotype and role, appropriate, malleable and reliable research models are indispensable. Therefore, we also give an overview of in vitro pituitary (stem cell) study models and the important improvements that have recently been achieved in this field, in particular by establishing organoids.

\section{PITUITARY STEM CELLS DURING KEY PHYSIOLOGICAL EVENTS OF POSTNATAL LIFE}

\section{Pituitary Stem Cells During Neonatal Maturation}

When born, although all hormonal cell types are specified in the pituitary, the gland still needs to further expand and mature (23, 24). Before birth, during embryonic development [extensively reviewed elsewhere (25-27)], the pituitary initially appears as a thickening and subsequent invagination of the oral ectoderm called Rathke's pouch (RP), occurring in the mouse at embryonic day (E)8.5. From this first recognizable "pituitary" structure, the AP and intermediate lobe [containing the melanocyte stimulating hormone (MSH)-producing melanotropes] eventually develop. Around E12.5, the pouch disconnects from the oral roof and forms a closed entity around a central lumen (the future cleft). The marginal zone (MZ) around this lumen houses the progenitor cells of the embryonically developing pituitary which proliferate and then start to colonize the nascent AP where they generate three main lineages from which the different hormonal cell types develop, i.e., the PIT1 lineage giving rise to somatotropes, lactotropes and thyrotropes; the SF1/GATA2 lineage from which the gonadotropes develop; and the TBX19 lineage turning into corticotropes $(25,26,28)$. This genesis of cell lineages and cell types is steered by a specific interplay between evolutionarily conserved signaling factors, such as bone morphogenetic proteins (BMP) and fibroblast growth factors (FGF), and sonic hedgehog (SHH), winglesstype MMTV integration site (WNT) and NOTCH family members, resulting in tightly regulated spatiotemporal expression of transcriptional regulators which govern the development of the distinct cell types $(25,26,29,30)$.

During the first postnatal weeks, the rodent pituitary almost doubles in size. This expansion and maturation process is driven by increased cell proliferation [including the re-entry of embryonically committed cells into the cell cycle (31)] and expansion of cell size because of endocrine differentiation with accumulation of hormone-containing secretory granules. In the rat, the proportion of proliferating cells in the postnatal pituitary is highest in the first week after birth to subsequently decline in the coming weeks toward very low levels at adulthood [i.e., from 
400 dividing cells $/ \mathrm{mm}^{2}$ in the first week to 50 dividing cells $/ \mathrm{mm}^{2}$ at 8 weeks of age $(17,32)]$. The basal adult pituitary indeed shows low turnover, with hormonal cells being replaced only every 6070 days [as estimated in the young-adult rat $(33,34)]$. Proliferation during neonatal maturation is observed not only in freshly differentiated, granular hormone-producing cells, representing $70-80 \%$ of the dividing population (32, 35-37), but also in non-hormonal agranular cells, at least partly identified as FS cells based on morphology and expression of the FS cell marker S100 $(17,38,39)$. Nowadays, it is known that the heterogenous FS cell population encompasses pituitary stem cells $(4,5,40)$.

Following the discovery of pituitary stem cells, several findings were reported that point to their potential involvement in neonatal pituitary growth and maturation. First, the proportion of stem cells is highest during the first postnatal week [i.e., postnatal day $(\mathrm{P}) 1-7$ versus $\mathrm{P} 21$, marking the end of the growth wave in mice, and versus adult age], as explored by both functional "side population" (SP) phenotype [a protective efflux capacity of stem cells $(3,4)$ ] and molecular $\mathrm{SOX}^{+}$nature (16). The topography of $\mathrm{SOX}^{+}$cells at birth shows multicellular layers in the $\mathrm{MZ}$, particularly prominent in the merging region of the anterior and intermediate lobe (referred to as the wedges) where "streams" of $\mathrm{SOX}^{+}$stem cells appear to move into the developing AP (16). Moreover, the stem cell compartment shows a higher activation status involving a larger proportion of proliferating $\mathrm{SOX}^{+}$cells. In accordance, neonatal pituitary stem cells show increased sphere formation capacity, further demonstrating their intensified functionality. Spheres (referred to as pituispheres) have been shown to develop from pituitary stem cells and sphere formation capacity is used as a readout of stem cell functionality and activation (3-5) (see further below). Additional support for the activated phenotype of neonatal pituitary stem cells includes their enhanced expression of stemness and embryogenesis-related genes (e.g., Sox2, Sox9, Prop1 and components of NOTCH, WNT and SHH pathways), and swifter differentiation into hormonal cells in pituisphere culture as compared to the adult pituitary stem cells (16). PROP1 is a transcription factor formerly considered only essential for the development of the PIT1-dependent cell lineages during pituitary embryonic development but nowadays endowed with a more general function in embryonic stem/progenitor cells, governing their migration from the MZ to the nascent AP (41). It was shown in vivo (using mutant mice) and in vitro (using stem cell-derived colony culture; see below) that PROP1 drives the stem/progenitor cells into epithelial-mesenchymal transition (EMT) which is considered to underlie their migratory movement toward the developing AP (42). PROP1 disappears during this transition from stem/progenitor cell state towards committed endocrine cell (41). The factor remains expressed in $\mathrm{SOX}^{+}$cells in the (rat) MZ acutely after birth, but the number of $\mathrm{PROP}^{+} / \mathrm{SOX}^{+}$cells decreases during further postnatal maturation, with PROP1-expressing cells becoming rare in the adult pituitary (43), although this issue is still not fully settled since another study showed persistent expression (40). Also, NESTIN, a classic neural stem cell marker, has been identified in pituitary stem cells $(3-5,44)$. The proportion of NESTIN $^{+}$cells rapidly decreases after birth [from $12 \%$ just before birth to $2 \%$ in the adult gland, as determined in rat (45)], whereas some of these cells remain proliferating which has led to the proposal that they represent the small proliferative fraction of the pituitary stem cells. The majority (70-80\%) of the neonatal NESTIN ${ }^{+}$cells coexpress PIT1 as well as dependent hormones (especially GH and PRL), suggesting that new hormonal cells might be differentiating from these $\mathrm{NESTIN}^{+}$progenitor cells (45). $\mathrm{PROP}^{+}$and $\mathrm{NESTIN}^{+}$stem/progenitor cells thus also appear to be involved in the neonatal growth and maturation phase of the (rat) pituitary gland, both strongly fading in abundance at later age.

Together, higher proportion and activation status of the resident stem cells suggest a role in neonatal development of the pituitary. Possible mechanisms include direct generation of new endocrine cells and/or paracrine stimulation of committed progenitor cells to proliferate and differentiate or of differentiated hormonal cells to proliferate and expand in number (Figure 1). The first hypothesis is supported by the finding of swifter differentiation pace of neonatal stem cells in pituisphere culture (16) and of more significant contribution of stem cells $\left(\mathrm{SOX}^{+}\right.$or $\left.\mathrm{SOX}^{+}\right)$to hormonal cells when transgenic lineage tracing is started in newborns (and analyzed 4 weeks later) versus in adulthood (6). Intriguingly, the largest contribution of traced stem cells was found in the gonadotrope population $(\sim 35 \%)$, which was proposed to be due to the use of tamoxifen to induce the lineage tracing, a selective estrogen receptor modulator which may affect gonadotrope development (6). Taken together, a clear view on degree and type of participation of stem cells in the neonatal phase of pituitary growth is not yet sketched. Further intriguingly, ablation of $\mathrm{SOX}^{+}$stem cells in the neonatal pituitary does not affect postnatal hormonal cell population development toward adult age (46). Increased proliferation in the remaining $\mathrm{SOX}_{2}{ }^{+}$cells acutely upon the ablation process may account for this rescue of hormonal cell development in the maturing gland. Alternatively, the ablation grade may have been too low (30\%) to provoke an effect in eventual hormonal cell population evolution (46). Fascinatingly, the stem cell population itself did also not restore to normal (as analyzed 4-6 months later) (46) which might indicate a redundancy of stem cells for normal postnatal pituitary development. Of note, double $\mathrm{SOX}^{+} /$hormone $^{+}$cells are not detected during neonatal maturation (neither in the basal adult gland), which may indicate that stem cells first need to downregulate or shut off SOX2 expression before hormone expression can be initiated (16).

At present, it is not clear which molecular mechanisms or regulatory networks underlie the activation status of the neonatal pituitary stem cell compartment [in detail reviewed elsewhere (30)]. Deletion of the NOTCH downstream effector RbpJ in embryonic Prop $1^{+}$progenitor cells leads to a significant decrease in proliferating $\mathrm{SOX}^{+}$cells in neonatal pituitary (from 30 to $15 \%)$, and almost complete absence of early-postnatal SOX2 ${ }^{+}$ cells (31). Moreover, re-entry of embryonically committed PIT $1^{+}$ cells into the cell cycle, as normally occurring shortly after birth, 


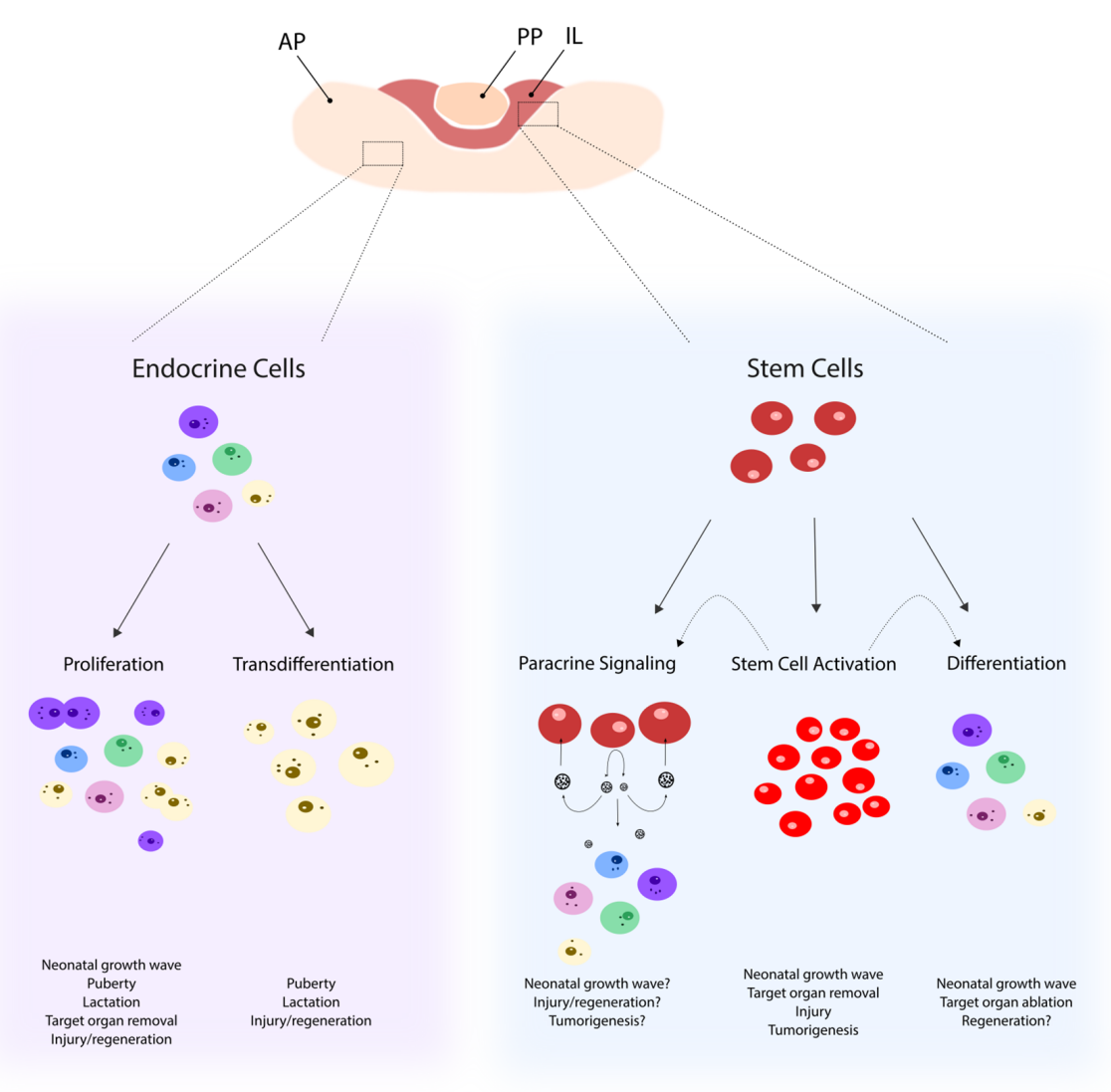

FIGURE 1 | Possible mechanisms underlying remodeling of the pituitary cell landscape. Pituitary remodeling during postnatal (patho-)physiological processes may involve differentiated endocrine cells that either proliferate (as, for instance, observed in the neonatal growth wave) or transdifferentiate (as, for instance, seen during puberty). In addition, the stem cell compartment may become activated (involving increased proliferation and upregulated stemness factors and signaling pathways) as, for instance, observed following pituitary injury. Pituitary stem cells, activated or not, may contribute to new endocrine cell formation during the pituitary remodeling events through differentiation (as, for instance, after target organ removal such as adrenalectomy) and/or through sending paracrine signals to surrounding cells (as, for instance, likely to occur during tumorigenesis). AP, anterior pituitary; PP, posterior pituitary, IL, intermediate lobe.

is drastically reduced. At adult age, the pituitary of these mice is hypoplastic with a clear decrease in all endocrine cell types thereby supporting an important role for NOTCH signaling in early-postnatal growth and maturation of the pituitary toward its adult form through governing both the $\mathrm{SOX}^{+}$cell self-renewal, maintenance and proliferation and the process and timing of $\mathrm{PIT}^{+}$cell re-entry into the cell cycle (31). Genetic deletion of Notch2, one of the NOTCH receptors expressed in the pituitary stem/progenitor cells during development and later in life (47, 48 ), as well as postnatal inhibition of NOTCH activity using the $\gamma$-secretase inhibitor DAPT, resulted in a similar phenotype, with decreased proliferation of the stem/progenitor cells and declined expression of the stem cell markers Sox2, Sox9 and Grainyheadlike 2 (Grhl2), a transcription factor found to be specifically expressed in the pituitary stem cells of the embryonic and earlypostnatal gland $(49,50)$. In agreement, it has been shown that the $\mathrm{NOTCH}$ target gene Hes 1 is indispensable in the correct control of progenitor cell expansion, since pituitaries lacking Hes1 exhibit decreased proliferation and increased cell cycle exit [with higher expression of cyclin-dependent kinase inhibitors such as p27 and p57 $(51,52)]$. Furthermore, Prop1 is a direct target of NOTCH signaling, thereby also assigning a role to PROP1 in the robust PIT1 lineage hormone cell expansion after birth (49).

Taken together, pituitary stem cells display an activated phenotype during the neonatal growth and maturation process of the gland. Despite emerging data and views, further research is needed to pinpoint their actual position in this active molding process, i.e., to decipher whether it involves direct contribution or stimulation of existing cells, or both, and to define the exact molecular regulatory mechanisms responsible for their activated status and function (Figure 1).

\section{Pituitary Stem Cells During Puberty}

Puberty encompasses sexual maturation of body and gonads, and growth of skeleton, bones, and organs. This key developmental process is essentially steered by hormones, in particular the gonadotropins $\mathrm{LH}$ and FSH (further mediated by their downstream effectors estradiol and testosterone), and $\mathrm{GH}$ [further mediated by liver-derived insulin-like growth factor-1 
(IGF-1)] which is responsible for the pubertal growth spurt (9, $53,54)$. The hypothalamic-pituitary-gonadal axis is already created and active in pre- and postnatal development. Its activity transiently declines during childhood (so-called "juvenile pause") but is re-activated at the onset of puberty, signaling the start of pubertal development (55).

Surprisingly little is known about cell adaptations in the pituitary gland during this key phase of life. In mice, somatotropes and lactotropes reach their full cell size at the onset of puberty and ultrastructural features become similar to their counterparts in adult gland. Other (non-)endocrine cell types reach final cell size and morphology about one week after puberty (56). The increasing levels of GH coincide with a peak in somatotrope markers (e.g., Poulf1, the gene encoding PIT1), although it is not clear yet whether there is higher expression of GH per somatotrope cell or whether somatotrope number expands (40). A study in children reaching puberty showed that rising $\mathrm{GH}$ levels are due to a rise in amplitude of the $\mathrm{GH}$ secretion peaks, not to an increase in pulse frequency (57). Whether pituitary stem cells are involved in remodeling of somatotropes during puberty, is not yet known.

Gonadotropes also change during puberty in number and activity. In medaka fish (Oryzias latipes), FSH- and LHproducing cells show hypertrophy and estradiol-driven proliferation during puberty (58). One study related to the involvement of stem/progenitor cells showed that genetically sustained Prop1 overexpression in gonadotropes results in delayed puberty as marked by decreased gonadotrope differentiation (with nearly absent $L h b$ and Fshb expression), less developed seminal vesicles in male mice and delayed vaginal opening, smaller ovaries and thinner uteri in female mice, as well as belated growth $(59,60)$. On the other hand, also knock-out (KO) of the Prop1 gene results in underdeveloped gonads (61). Human patients with PROP1 mutations either do not enter or complete pubertal development, show growth failure and need sex hormone substitutions (62). Taken together, PROP ${ }^{+}$ pituitary stem/progenitor cells might play a role in normal pubertal development and the needed pituitary gonadotrope and somatotrope cell remodeling (Figure 1), but hard, convincing evidence is not available yet.

\section{Pituitary Stem Cells During Pregnancy and Lactation}

Successful pregnancy and lactation largely depend on the action of, and regulation by PRL. Accordingly, PRL levels are substantially increased during these physiological states and processes (10-12). Whether this rise is substantially due to increasing numbers of lactotropes in the pituitary and if so, how new lactotropes emerge (i.e., proliferation of existing PRLproducing cells, transdifferentiation from somatotropes or differentiation from stem/progenitor cells), is still not unambiguously underpinned (Figure 1).

In rats, a peak in proliferating lactotropes is observed in late pregnancy (day 19-21 of gestation) resulting in an augmented proportion of $\mathrm{PRL}^{+}$cells during lactation when proliferative activity already returned to the (low) baseline level $(63,64)$. In humans, lactotrope hyperplasia occurs in various phases of pregnancy, assigned to both proliferation of pre-existing $\mathrm{PRL}^{+}$cells and transdifferentiation of somatotropes to lactosomatotropes [i.e., cells expressing both PRL and GH (65)]. In mice, no increase in lactotrope cell number was observed during lactation, but cell size of individual lactotropes was enlarged and cells formed long-lasting networks that enabled cell-cell communication and functional connectivity to coordinate elevated PRL secretion (10). Using PRL $\mathrm{PYFP/+}^{\mathrm{PF}}$ reporter mice, a $20 \%$ volume increase of the "enhanced yellow fluorescent protein"-positive $\left(\mathrm{eYFP}^{+}\right)$cell population was found during lactation, but this study did also not observe a rise in the proportion of $\mathrm{PRL}^{+}$cells (66). Still, proliferation may have occurred in the lactotrope progenitor cell population, a possibility supported by another study that also did not perceive an increase in proliferating $\mathrm{PRL}^{+}$cells (neither in $\mathrm{SOX}^{+}$stem cells) during lactation, but detected a large surge in proliferating $\mathrm{PIT}^{+}$progenitor cells $(31)$. Transdifferentiation between PRL ${ }^{\text {YYFP/+ }}$ and $\mathrm{GH}^{+}$cells was found to be low (less than $1 \%$ ), excluding a major contribution of such conversion process during lactation in the mouse (66). Since a large volume increase of the pituitary (peaking at mid-lactation) was seen, which could not fully be explained by the increased volume of the $\mathrm{eFFP}^{+}$cell population, a non-cell specific, general increase in mitosis was suggested (66). In analogy, a general increase in proliferating AP cells toward the end of pregnancy was also observed by Zhu et al. (31), with $\mathrm{SOX}_{2}{ }^{+}$stem cells remaining mostly quiescent (31). On the other hand, estradiol, a regulator of PRL production during lactation, induces a small, $10 \%$ increase in dividing $\mathrm{SOX}^{+}$ cells (6).

A novel and powerful technology to unravel tissue cell landscape and dynamics is provided by single-cell RNAsequencing (scRNA-seq). In a recent study interrogating the pituitary of 13-week old lactating mice and age-matched virgin control animals (67), expansion of the lactotrope cluster was observed in the lactating mice (36\% as compared to $29 \%$ in control), also showing upregulated expression of the neuroendocrine vesicle secretory protein chromogranin B $(C h g b)$. Upregulation of PRL levels during lactation thus may reflect the combined effect of an expanded lactotrope population and a more active PRL-secretory machinery. Authors further speculated that the newly formed lactotropes are derived from multi-hormonal cells, since the latter cluster is reduced in abundance during lactation $(10 \%$ as compared to $13 \%$ in control), expression of $\mathrm{Prl}$ within this remaining multihormonal cluster significantly upregulated and expression of other hormone transcripts (e.g., Lhb) downregulated. In addition, transdifferentiation of somatotropes to lactotropes was also proposed to play a role since $\mathrm{Prl}$ expression was clearly higher in the somatotrope cluster of lactating animals. Importantly, whether stem cells are involved in the expansion of the lactotrope population was not looked at or speculated on. Interestingly, the stem cell cluster appeared to become smaller in the lactating animals [3.2\% as compared to $4.5 \%$ in control (67)].

After weaning of the progeny, lactotrope cell number returns to normal steady-state levels, supposedly through a combination 
of apoptosis and transdifferentiation away from the lactotrope phenotype. However, using the $\mathrm{PRL}^{\mathrm{eYFP} /+}$ reporter mouse line, transdifferentiation was only observed at very limited rate [i.e., $\mathrm{GH}^{+}$cells derived from lactotropes did not exceed 1\% (66)].

Taken together, current data do not point to a significant role for stem cells in the generation of new lactotropes during pregnancy and lactation, but rather endow the committed progenitor cells with this function. Either, further and more detailed stem cell lineage tracing may indicate otherwise, or stem cells may rather play a nutritive, paracrine regulatory, or stimulatory role (Figure 1).

\section{Pituitary Stem Cells During Aging}

Aging is associated with a deterioration in tissue homeostatic turnover and reparative capacity. In some tissues such as muscle, this waned behavior is causally associated with decreased stem cell number and functionality (68-71). Manifestations of aging are also observed in the endocrine system, including in pituitary output. Higher baseline TSH levels and altered ACTH dynamics have been observed in the aged population (18). In rat, thyrotrope cell number decreases with age, but $\mathrm{TSH}^{+}$cell area (volume density) and TSH serum levels increase (72), consistent with observations in humans (18). These findings suggest a desensitization of the pituitary-thyroid axis during aging. Gonadotropes also show aging-associated changes. In the male rat pituitary, gonadotrope cell number and size decrease with a phenotypic shift from large to small vesicles in the cells, the latter being the main type present in the female gland $(73,74)$. FSH and LH levels decrease with aging in male rats, whereas they remain constant or even rise in female rats. Signs of degeneration (such as pyknosis) are observed in the aging gland gonadotropes (73). One of the best known aging-associated endocrine events is the so-called somatopause, a progressive fall in basal GH levels and resultant circulating IGF1 (75). Especially the GH pulse amplitude, but not the frequency, is reduced in aged individuals (18). In rats, number of $\mathrm{GH}^{+}$cells was not found different between young (3-month old) and old (24-month old) animals (76). By contrast, in mice and humans $\mathrm{GH}^{+}$cell number decreases at aging $(77,78)$. In addition to these putative local pituitary causes of dropped $\mathrm{GH}$ levels, also regulators of $\mathrm{GH}$ production alter when getting older, viz. dropped levels of activators such as ghrelin and GHRH and rising concentrations of inhibitors such as somatostatin. Furthermore, changed sensitivity to these regulators may play a role including a gender-independent decline in $\mathrm{GH}$ cell responsiveness to GHRH and ghrelin $(79,80)$.

Although involvement of pituitary stem cells in the gland's aging phenotype has been regularly hypothesized $(2,21)$, this assumption is at present only scarcely supported. FS cells, known to encompass pituitary stem cells, are decreased in number in old rats [from 4.5 cells per reference area in young rats to 1.5 in old rats (81)]. However, in human pituitary, FS cell number was found to be expanded (82), an increase which might be grounded in the stem cell fraction of the heterogeneous FS cell population, but also in the stromal or immune subpopulations. In other tissues like muscle and heart, it has been observed that the stem cell population is negatively affected by age, presenting as a decline in number and in regenerative capacity (68-71). Interestingly, restorative capacity of the pituitary also fades at aging, in a quite speedily manner. Following infliction of injury in the gland of middle-aged (8- to 10-month old) mice using the GHCre/iDTR model (see below), regeneration-which plainly unfolds in young 8-12-week old animals-does not occur any longer. This regenerative failure in older mice coincides with a decline in pituitary stem cell number and fitness [i.e., decreased sphere formation capacity (21)].

Taken together, several changes occur in the pituitary's cell landscape and hormonal output during aging, but at present, barely anything is known about the impact of aging on the local stem cells and their participation in these changes. The least that is known is that their number, activity and fitness appear to decline, as occurring with stem cells in many other tissues (21, 68-71).

\section{PITUITARY STEM CELLS DURING PHYSIO-PATHOLOGICAL CONDITIONS}

\section{Pituitary Stem Cells During Stress}

Stress is a physiological coping mechanism marked by activation of the hypothalamic-pituitary-adrenal (HPA) axis and essentially resulting in increased levels of circulating ACTH and glucocorticoids (cortisol in humans and corticosterone in mice). Other pituitary hormones are also affected by stress with impact depending on severity and exposure time $(13,83)$.

In mice, acute $(30 \mathrm{~min})$ cold stress does not result in immediate changes of corticotrope cell number, although corticosterone levels rise (14). The relative abundance of the other AP cell types is increased at the expense of non-hormonal cells. Since these changes occur acutely after application of the stressor, it was proposed that the new endocrine cells develop through maturation of committed progenitor cells that already transcribe or translate minimal (undetectable) amounts of hormone and rapidly increase this expression upon stress. In contrast, a 30 min cold exposure in rats was found to result in an increase in $\mathrm{POMC}^{+}$and $\mathrm{ACTH}^{+}$cell number and size (15). Another study also showed an expansion of cells expressing Pomc mRNA (as analyzed by in situ hybridization) 2-3 h after applying a cold stressor in rats (84). Exposure to chemical stressors (such as formaldehyde) also results in a rise of $\mathrm{ACTH}^{+}$cell proportion as analyzed in mice (85). Following exposure of rats to increased ambient temperature, $\mathrm{ACTH}^{+}$cells show reduced volume density, likely due to elevated secretion of ACTH from the corticotrope cells, which is concordant with the higher levels of ACTH (and corticosterone) found in the circulation (86).

Apart from the corticotropes as logical stress target, also other pituitary hormonal cells are affected. Thyrotropes respond to acute cold in rats by expanding in number and size (15). Somatotrope dynamics change depending on the type of stressor. Pituitary GH protein levels in rats increase upon acute immobilization or restraint but not after repeated immobilization. However, size and density of $\mathrm{GH}^{+}$cells remain 
largely comparable to control (87). Prenatal dexamethasone treatment in rats, resulting in intensified HPA activity in postnatal life-and thus a chronically elevated stress statetriggered long-term changes in FS cell morphology but not number, whereas not affecting the corticotrope population (88).

In the HPA axis, the adrenal gland negatively feeds back through corticoids to the hypothalamus and pituitary, thereby keeping ACTH production under control. Hence, adrenalectomy causes a rise in ACTH level and a transient increase in $\mathrm{ACTH}^{+}$cells in the pituitary (33). Mechanisms underlying this corticotrope remodeling include increased proliferation of existing $\mathrm{ACTH}^{+}$ cells which thus re-enter the cell cycle $\left[4.5 \%\right.$ dividing $\mathrm{ACTH}^{+}$ cells per unit area after adrenalectomy as compared to $0.5 \%$ in control (89)] and development of new corticotropes from stem cells, as demonstrated by SOX9 lineage tracing [i.e., $20 \%$ of the new $\mathrm{ACTH}^{+}$cells originate from the traced cells (6)]. Another study showed an increase in proliferating $\mathrm{TBX} 9^{+}$corticotrope progenitor cells after adrenalectomy (90).

Overall, although pituitary cell remodeling during or following stress has been studied in different models, not much is known yet on whether and how pituitary stem cells play a role (Figure 1).

\section{Pituitary Stem Cells During Tumorigenesis in the Gland}

Tumors in the pituitary gland, nowadays referred to as pituitary neuroendocrine tumors (PitNETs), represent 15\% of all intracranial lesions and occur as symptom-causing tumors with a prevalence of 1 in $1,000(1,91)$. PitNETs can cause serious morbidity through hormone hypersecretion or, at the other side of the spectrum, reduced pituitary function (hypopituitarism) because of compressing healthy, neighboring pituitary tissue (1, 91). Not much is known on the underlying pathogenesis of PitNETs and their link with pituitary stem cells has so far only scarcely been studied. In search for so-called tumor stem cells (TSC), defined as cells driving tumor initiation, growth and heterogenic composition (thus displaying the orthodox stem cell properties of self-renewal and multipotency), and responsible for tumor re-growth after therapy because of their increased resistance, a SP was found in human and mouse PitNETs showing tumorsphere formation, expression of stemness markers and in vivo growth capacity, all pointing to a TSC character (92). Also other studies provided data proposing the existence of TSC in pituitary tumors [extensively reviewed in (93)]. Using a mouse model of lactotrope tumor (prolactinoma) formation in the pituitary (i.e., $\mathrm{Drd} 2^{-/-}$mice), an increase in SOX2 ${ }^{+}$ cells was found in the tumorous gland, at least partly due to elevated proliferative activity (92). These findings suggest that the resident pituitary stem cells are activated in case of the "threatening" tumorigenic event in the gland. Whether this reaction is preventing fierce tumor growth progression, or is otherwise stimulating the process, is not known. Moreover, the $\mathrm{SOX}^{+}$cells may not only represent activated tissue stem cells but also TSC developed from the(se) stem cells (or alternatively from other cell types by, for instance, dedifferentiation). However, direct descent of tumor cells from $\mathrm{SOX}_{2}{ }^{+}$cells was not supported in the $\operatorname{Drd} 2^{-/-}$mouse using $\mathrm{SOX} 2^{+}$lineage tracing (93), thus questioning their role as TSC. Rather, paracrine stimulation of tumor formation and growth may occur (Figure 1), as has also been reported in another pituitary-located tumor model (94). Transgenic expression of a genetically mutated, constitutively active form of the WNT signaling transducer $\beta$ catenin in embryonic pituitary progenitor cells (95) or in SOX2 ${ }^{+}$ cells (7) results in the development of lesions in the gland showing characteristics of adamantinomatous craniopharyngoma (ACP), a benign but burdening tumor mostly occurring in children (96). The tumors contained typical nucleocytoplasmic $\beta$-catenin ${ }^{+}$cell foci expressing the stem cell markers SOX2 and NESTIN $(7,95)$. However, $\mathrm{SOX} 2^{+}$lineage tracing revealed that the tumor proper did not directly derive from the $\mathrm{SOX}^{+}$stem cells, which, on the other hand, were characterized to produce several factors that could fuel tumor development and growth from the neighboring cells $(7,94-96)$. Intriguingly, tumors did not develop when $\beta$ catenin was transgenically expressed in committed $\left(\mathrm{PIT}^{+}\right)$or differentiated $\left(\mathrm{GH}^{+}, \mathrm{PRL}^{+}\right)$cells, indicating an essential (although indirect) role of stem cells in this tumorigenic process (95). In accordance with the aberrantly activated WNT pathway in the stem/progenitor cells of this ACP-resembling model, upregulated expression of WNT components has also been observed in the SP of human PitNETs (92). Other typical stem cell-regulating pathways that have been advanced to potentially play a role in pituitary tumorigenesis are the NOTCH pathway, which seems either activated or suppressed in the tumor (analyzed as a whole), depending on the pituitary tumor subtype (97), and the HIPPO pathway. Elevated expression of HIPPO pathway components (e.g., YAP1, LATS2) was detected in the SP of PitNETs (92). Moreover, genetically induced elevation of YAP/TAZ signaling in the SOX $2^{+}$pituitary stem cells results in the development of nonsecreting aggressive tumors (98). Intriguingly, in contrast to the $\mathrm{Drd2}^{-/-}$prolactinoma and ACP-resembling models described above, these tumors directly (and clonally) originated from deregulated $\mathrm{SOX}^{+}$cells as investigated using $\mathrm{SOX} 2^{+}$lineage tracing (98). However, these highly proliferative carcinomaresembling tumors do not immediately draw a parallel with the typically benign tumors that occur in the pituitary. Finally, a recent study, clustering pituitary tumors by RNA-seq analysis in three groups coinciding with canonical lineage transcription factors [i.e., TBX19, NR5A1 (SF1) and POU1F1 (PIT1)], did not reveal a transcriptomic link with the (normal) stem cell population, but suggested that the "tumor progenitor cells" (TSC) derive from already (partially) committed cells expressing the respective transcription factor (99).

Taken together, although more and more studied, no clear view is shed yet on the connection between pituitary stem cells and tumorigenesis in the gland. It remains essential to decipher whether and how pituitary stem cells are implicated in order to advance our knowledge on pituitary tumorigenesis, at present only poorly understood. Of note, the local stem cells may become "activated" during tumorigenesis not only by genetic or molecular (signaling/ growth factor) aberrations, but also by the accompanying physical tissue damage, a reaction indeed observed following inflicted injury in the gland. 


\section{Pituitary Stem Cells Following Injury in the Gland}

Hypopituitarism, involving deficiency in one or more pituitary hormones, results in serious morbidity given the gland's central position in the endocrine system (100). This hypofunction may be due to faults in embryonic development, or may be caused by damage occurring during postnatal life. Culprits include hemorrhagic necrosis in the gland (Sheegan's syndrome), physical damage by tumor growth as well as following its operational resection, and destructive impact on the gland through head trauma [traumatic brain injury (TBI)] as caused by traffic, sport or violence accidents. To define the behavior of the gland's stem cells following injury, a transgenic mouse model was created allowing the destruction of pituitary cells (19). Before, partial hypophysectomy had been applied which is technically challenging and difficult to standardize. An older study in rats reported an increase in "chromophobic" cells in the residual pituitary after partial tissue removal, which may represent the immature (stem) cells $(22,101)$. However, no cell regeneration or anatomical restoration was observed, even up to one year later (101). In the more recent transgenic pituitary injury model, specific cell populations are targeted for killing by diphtheria toxin (DT) treatment. In the GHCre/iDTR mouse model, expression of the DT receptor (DTR) is induced (hence, "inducible" or iDTR) through the activity of Cre recombinase, expressed under control of the GH promoter. DTR in the GHexpressing cells then makes these cells sensitive to DT-induced ablation. A 3-day DT injection results in major (80-90\%) obliteration of the somatotrope cells, thereby realizing a controlled pituitary injury model (19). Interestingly, the resident stem cells promptly react to the cell-ablation damage in the gland. First, it was found that the stem cell population shows augmented proliferative activity and expands (about 2fold) upon injury based on several read-outs including SP, FS cell and $\mathrm{SOX2}^{+}$phenotype and sphere-initiating capacity (19). Morphologically, especially the wedge regions show a prominent enlargement of the SOX $2^{+}$stem cell zone (19). In addition, upregulated gene expression of factors typically associated with stem/progenitor cells and/or with pituitary embryogenesis (such as FGF, BMP, and components of the SHH, WNT, and NOTCH signaling pathways), further supported the activated status of the pituitary stem cell pool following injury. Similar facets of stem cell activation were observed in a complementary pituitary injury model killing the PRL-expressing cells (with 70\% ablation grade) using the PRLCre/iDTR mouse model (20). Finally, a proliferative activation reaction was also detected in the remaining $\mathrm{SOX2}^{+}$ cell compartment after DT-targeted SOX2 ${ }^{+}$cell ablation (46). However, this response only unfolds in early-postnatal mice (1-4 weeks of age), not in adult animals (8-12 weeks), and does not result in restoration of $\mathrm{SOX}_{2}{ }^{+}$cell numbers as analyzed 4-6 months later (see above).

Interestingly, a significant restoration of the ablated cell population was noticed, thereby convincingly demonstrating for the first time that the adult pituitary gland possesses regenerative capacity. The number of somatotropes is restored to $50-60 \%$ after $4-5$ months [GHCre/iDTR model (19)]. Also GH serum levels substantially re-lift [to $30 \%$ (21)]. However, regeneration does not reach higher levels, even following an extended follow-up period (19 months) after the somatotrope ablation insult, suggesting that full regeneration is not critical for survival and supportable life (21). Since the stem cell compartment is activated upon injury followed by tissue repair, the question presented whether stem cells are involved in the regenerative response. Co-expression of SOX2 and GH surfaces in several cells, not observed in the normal steady-state gland, thereby pointing to differentiation of (reacting) stem cells toward the somatotrope fate. No evidence was found for contribution of other mechanisms such as transdifferentiation from lactotropes (no increase in $\mathrm{PRL}^{+} / \mathrm{GH}^{+}$cells) or proliferation of remaining somatotropes [dividing $\mathrm{GH}^{+}$cells are virtually non-existent (19)] (Figure 1). Nevertheless, direct demonstration of the descent of the newborn $\mathrm{GH}^{+}$cells from the $\mathrm{SOX} 2^{+}$stem cells awaits lineage tracing, however at present technically difficult using a Cremediated approach. For instance, tamoxifen-induced SOX2CreERT-driven lineage tracing after GHCre-mediated somatotrope ablation cannot exclude simultaneous tracing of the remaining GH cells (also expressing Cre) and will thus not allow to discern between reporter ${ }^{+}$cells derived from $\mathrm{GH}^{+}$or $\mathrm{SOX}^{+}$cells during the regenerative period. As an alternative mechanism underlying regeneration, the activated stem cells may act as restoration-stimulating signaling center, for instance driving the $\mathrm{PITl}^{+}$progenitor cells into proliferation [as apparently also occurring in pregnancy/lactation and probably also during neonatal maturation, as discussed above (31)] (Figure 1). Involvement of stem cells in the regenerative reaction, whatever the mechanism, is further supported by upregulated gene expression in the stem cells of factors belonging to pathways typically involved in tissue regeneration such as the epidermal growth factor (EGF), FGF, EMT, and Hippo signaling systems (21), and of factors playing a role in pituitary embryogenesis (see above), suggesting recapitulation of the embryonic developmental program, as also reported in other regenerating tissues such as muscle (102). In the PRLCre/iDTR model, the lactotrope population shows a swifter restoration, reaching $60-70 \%$ after $6-8$ weeks (20). The more efficient repair is likely due to the accumulated action of multiple regenerative processes in this cell lineage, including stem cell differentiation (increase in $\mathrm{SOX}^{+} / \mathrm{PRL}^{+}$co-expressing cells), amplification in lactotrope proliferation (as observed) and transdifferentiation of somatotropes to lactotropes [increase in cells co-expressing GH and PRL (20)] (Figure 1). Formerly, some signs of regeneration were also briefly reported following thymidine kinase-mediated obliteration of somatotropes and lactotropes (103). However, underlying mechanisms, and particularly the involvement of stem cells, were not investigated at that time. Moreover, this nucleotide (FIAU)-incorporating approach only kills cells that are actively dividing and therefore necessitated FIAU treatment from the embryonic till early-postnatal stage (103), thus excluding applicability of the technique for cell ablation and regeneration studies in the predominantly non-mitogenic adult pituitary. 
TBI is increasingly recognized as an important cause of hypopituitarism with drop in hormone levels (especially GH and ACTH), possibly due to damage to the pituitary tissue, either directly or through hypothalamic or vascular impacts $(104,105)$. It has been found that hormone serum levels in TBI patients may restore after several (3 to 36) months (104, 106-108). Whether this recovery is due to compensatory behavior of the remaining pituitary cells or the hypothalamus-pituitary axis, to regained pituitary cell functionality, or to repair of the pituitary insult with new cell formation to replace damaged and destroyed cells, is not known $(104,105)$. Further in-depth investigation of the pituitary cell landscape upon TBI, for instance using scRNA-seq analysis, is expected to provide deeper insight into (stem) cell reaction and possible repair, and into TBI-induced hypopituitarism, which may eventually lead to new approaches to clinically deal with this prevalent endocrine deficiency condition.

Taken together, the resident stem cell compartment of the pituitary promptly reacts to injury in the gland, which may lead to ensuing regenerative processes. However, underlying mechanisms, whether it involves direct generation of new cells or indirect paracrine stimulation of cell neogenesis, still need to be clearly defined (Figure 1). In the longer run, this knowledge may pave the way to regenerative therapies in case of damage-induced hypopituitarism such as by tumor operation or head trauma. Pituitary stem cells could potentially be stimulated in vivo to drive new-formation of destroyed endocrine cell type(s), or may ex vivo be expanded, differentiated and transplanted, as proposed already a long time ago in a study in which chromophobes (freshly isolated from the pituitary) were shown to divide and differentiate when transplanted into the hypophysiotropic area of the rat (109). Alternatively, the secretome of activated pituitary stem cells, when functioning as signaling centers, may be defined and important factors applied as treatment in vivo (22) (Figure 1). As an important remark, it is still unclear whether also the human pituitary is capable of regenerating. Only very few studies addressed this issue. Following transsphenoidal electrocoagulation-mediated destruction of metastasized tumors in the gland (thus damaging the pituitary tissue), actively dividing chromophobic cells around the necrotic core and signs of glandular regeneration were observed in post-mortem pituitaries (110). As described above, restoration of pituitary function in terms of circulating hormone levels after TBI might also involve pituitary regeneration although at present not investigated. Clinical endurance of hypopituitarism, when brought about by local tumor growth or removal, does not immediately point to a restorative response. However, transient regenerative processes may occur which are stalled for one or the other reason, but which cannot be probed in human beings and will need innovative in vitro approaches.

\section{IN VITRO MODEL SYSTEMS TO STUDY PITUITARY STEM CELLS AND REMODELING}

Although studies in experimental animals, in particular mice, have generated important information on pituitary development and functioning, there is a high need for appropriate in vitro research models to study pituitary stem cell biology and pituitary (cell) remodeling, and their cross-section. Over the years, several different pituitary in vitro models have been developed, ranging from $2 \mathrm{D}$ immortalized cell lines to 3D structures, each with own specific sets of advantages and shortcomings (Table 1). Here, we give a short overview of the different model systems and their potential as research tool to untangle pituitary remodeling and in particular the biology, role and regulation of the pituitary stem cells in these plastic adaptations.

\section{Pituitary Cell Lines}

Cell lines have been developed that represent different pituitary cell types. The lines were derived by culturing pituitary tumors or by genetically transforming and immortalizing pituitary cells or specific cell types. Well-known examples are the mouse corticotrope AtT20 cell line and the rat lactosomatotrope GH3 cells. The cell lines proved valuable to study hormone regulation by hypothalamic and other factors $(111,112)$. FS cell lines have also been established [e.g., PDFS (113)] and have been instrumental to study cytokine regulation of AP cell functions $(114,115)$ and intrapituitary communication $(111,116)$.

Despite their value, cell lines have important shortcomings in mimicking pituitary (cell) physiology, in particular because of their transformed pheno-/genotype (usually aneuploid and neoplastic), their 2D culture format (contrasting with the $3 \mathrm{D}$ configuration and anchoring in vivo), and their poor or nonexisting representation of the compound pituitary cell composition. On the other hand, the cell lines still appear to contain a (driving)? progenitor cell population. For instance, SP cells were identified in AtT20 and GH3 cells showing stemness functionality such as sphere formation and xenotransplant tumor growth (92).

\section{Model Systems Established From Primary Pituitary}

\section{Models Starting From the Compound Pituitary}

Primary cells from dissociated pituitary glands can be cultured as monolayers, either as original mixture or following enrichment of specific cell types using sedimentation gradients $(117,118)$ or counterflow centrifugation (119). Although easy to achieve, the resultant $2 \mathrm{D}$ cultured cells quickly (within one week) start to deteriorate, lose their normal physiological behavior and responsiveness (e.g., to hypothalamic hormones), and die.

Alternatively, primary pituitary tissue can be kept in culture as explants, frequently employed in the past $(49,120,121)$. To do so, pituitary tissue fragments (e.g., halved glands) are cultured either submerged in optimized culture medium (composition differing between studies), or deposited at the air-liquid interface [e.g., RP explants $(29,122,123)$ ]. Although physiological responses are elicited in explant cultures, their "shelf life" is limited because of inadequate perfusion, lack of sufficient oxygenation and resulting necrosis in the core (after a few days in culture).

Above-mentioned shortcomings are overcome in an organotypic culture system of pituitary cell aggregates (44, 48, 
TABLE 1 | Pros and cons of in vitro pituitary study models.

\begin{tabular}{|c|c|c|}
\hline Model & Pros & Cons \\
\hline Pituitary cell lines & $\begin{array}{l}\text { - Readily available } \\
\text { - Easy to handle and manipulate }\end{array}$ & $\begin{array}{l}\text { - Tumor-derived or genetically immortalized (not representative for } \\
\text { normal tissue cells) } \\
\text { - Only represents a single cell type } \\
\text { - 2D format }\end{array}$ \\
\hline From primary com & nd pituitary & \\
\hline $\begin{array}{l}\text { Monolayer cell } \\
\text { culture }\end{array}$ & $\begin{array}{l}\text { - More pituitary cell types } \\
\text { - Easily established }\end{array}$ & $\begin{array}{l}\text { - Limited expandability } \\
\text { - Quickly lose physiological behavior } \\
\text { - 2D format }\end{array}$ \\
\hline Explant culture & $\begin{array}{l}\text { - Representative (reflects tissue heterogeneity and physiological } \\
\text { responses) } \\
\text { - Easily established } \\
\text { - 3D format }\end{array}$ & $\begin{array}{l}\text { - Limited expandability - necrosis } \\
\text { - Limited experimental possibilities or manipulations }\end{array}$ \\
\hline $\begin{array}{l}\text { Cell aggregate } \\
\text { culture }\end{array}$ & $\begin{array}{l}\text { - Representative (reflects tissue heterogeneity and physiological } \\
\text { responses) } \\
\text { - Easily established } \\
\text { - Long-term culture } \\
\text { - } 3 \text { D format }\end{array}$ & $\begin{array}{l}\text { - Limited expandability } \\
\text { - Difficult to enrich for FS/stem cells }\end{array}$ \\
\hline \multicolumn{3}{|c|}{ From primary pituitary stem cells } \\
\hline Sphere culture & $\begin{array}{l}\text { - Quite representative (differentiation into hormonal cells) } \\
\text { - Allows exploration of pituitary stem cell biology } \\
\text { - 3D format }\end{array}$ & $\begin{array}{l}\text { - Limited expandability } \\
\text { - Limited application potential (e.g., to unravel differentiation } \\
\text { processes) }\end{array}$ \\
\hline Colony culture & $\begin{array}{l}\text { - Quite representative (differentiation into hormonal cells) } \\
\text { - Allows exploration of pituitary stem cell biology }\end{array}$ & $\begin{array}{l}\text { - Limited expandability } \\
\text { - Limited application potential (e.g., to unravel differentiation } \\
\text { processes) } \\
\text { - 2D format }\end{array}$ \\
\hline Organoid culture & $\begin{array}{l}\text { - Extensive expandability of limited primary (stem) cells } \\
\text { - Quite representative (differentiation into specific hormonal cells) } \\
\text { - Allows exploration of pituitary stem cell biology } \\
\text { - High application potential (e.g., tumor/disease modeling, drug } \\
\text { screening, ...) } \\
\text { - Amenable to gene editing } \\
\text { - Cryopreservable } \\
\text { - 3D format }\end{array}$ & $\begin{array}{l}\text { - Cost-intensive } \\
\text { - At present still limited differentiation } \\
\text { - Very hard to achieve from normal human pituitary }\end{array}$ \\
\hline From PSCs & & \\
\hline Organoid culture & $\begin{array}{l}\text { - More representative (may reflect tissue heterogeneity) } \\
\text { - ESCs/iPSCs are readily available and expandable } \\
\text { - Model for human normal pituitary } \\
\text { - 3D format }\end{array}$ & $\begin{array}{l}\text { - Labor intensive set-up } \\
\text { - Cost-intensive } \\
\text { - Limited expandability once differentiated into pituitary fate } \\
\text { - Human iPSCs known difficult to transfect }\end{array}$ \\
\hline
\end{tabular}

124, 125). Dissociated primary pituitary cells (typically from rat or mouse) are cultured under constant gyratory movement in a pituitary-optimized, serum-free defined medium (SFDM), allowing the cells to re-aggregate and form histotypic cultures containing all main pituitary cell types [including FS and stem cells but lacking primary pituitary endothelial cells and housed lymphocytes and monocytes (48)], thereby reflecting the major pituitary cell composition as well as cell type-typical organization. Pituitary cell (re-)aggregates can be kept in culture for months without losing tissue and cell-type representation and functionality (i.e., hormone production capacity and regulation with responsiveness to hypothalamic hormones). As true in the in situ gland, not much cell proliferation is occurring in the aggregates, and cultures are not expanding but static in abundance. Although aggregates can be formed from enriched endocrine cell types, no aggregates have been established from isolated stem cells, and aggregates from enriched FS cells remain small and fragile (44, 48, 124, 125).

\section{Non-Organoid Models Derived From Pituitary Stem Cells}

A common and essential shortcoming of the above-mentioned pituitary model systems is that at present none of them allows to specifically grow and study the stem cell compartment. In vitro study models for pituitary stem cells are essential to advance our knowledge on the behavior (self-renewal, multipotent 
differentiation, activation), regulation and translational and clinical potential of this still under-defined pituitary cell population.

Clonal sphere formation is a general characteristic of stem cells, which was first defined for neural stem cells (126). Cultured in a specific growth medium including B27, EGF and/or basic FGF (bFGF/FGF2), stem cells clonally expand to form floating 3D spheres that can be serially passaged, based on the capacity of the sphere-initiating stem cell to self-renew and generate proliferative progenitor cells. Under specific culture conditions, differentiation to various cell types of the tissue of origin occurs in the spheres because of the (multipotent) differentiation capacity of the originating stem cell (126). Free-floating spheres can be derived from pituitary by culturing dissociated AP cells in SFDM (or other culture medium) supplemented with B27 and bFGF. These so-called pituispheres are composed of $\mathrm{SOX}^{+}$stem cells [also expressing other pituitary stem cell markers such as NESTIN, E-cadherin, S100 and SOX9 (3-5)], originate from the SP [and not from the non-SP (3)] and from the $\mathrm{SOX}^{+}$stem cells (6), and can be differentiated toward all pituitary hormonal cell types by culturing on an ECM (Matrigel)-coated surface in medium without stem cell growth factors. Pituispheres (when formed after 6 days of culture) can be dissociated and resultant cells re-seeded to grow new spheres, although the propagation efficiency gradually but quickly declines, being at present limited to 3-4 serial passages (3-5, 40). This stem cell model has proven its merits, mainly as readout of stem cell functionality and activation (3-6, 16, 19, 31, 46, 48). For instance, more spheres are formed when starting from the damaged GHCre/iDTR pituitary, in line with the activated status of the stem cells upon injury [see above $(19,21)]$.

Another general test to probe stem cell phenotype and functionality is provided by the colony-forming assay, which, in contrast to the sphere assay, occurs in $2 \mathrm{D}$ format. Dissociated pituitary cells, cultured in medium containing serum, bFGF and cholera toxin, generate colonies after 6 days that express the stem cell markers NESTIN and SOX2, as well as limited levels of early pituitary development markers (LHX3), the latter increasing toward 14 days in culture (coinciding with the exit of the exponential growth phase in the colony). Eventually, the colonies contain cells of all five AP cell lineages, although at modest numbers $(7,96,127)$.

Although valuable for specific readouts of stem cell functionality (probed by, for instance, colony-forming efficiency), the 2D format does not mimic the 3D anchoring and interaction of cells as present in vivo. Despite a 3D configuration, pituispheres remain limited in growth and application potential. Hence, a more versatile and efficient model system would definitely be instrumental to study pituitary and stem-cell biology in vitro. Over the last years, so-called organoid models have been developed, either derived from pluripotent stem cells (PSCs) or from pituitary stem cells.

\section{Organoid Models Established From Pluripotent and Pituitary Stem Cells}

In their contemporary meaning, organoids represent composite cell configurations that in vitro grow from (single) stem cells that self-renew, proliferate and self-organize in $3 \mathrm{D}$, eventually replicating key biological properties of the organ of origin $(128,129)$. Such present-day organoid modeling has been achieved starting from tissue stem cells and from PSCs.

Tissue stem cell-derived "organoid-ing" typically follows the principles that were laid down in the first successful development of such organoids (130). Tissue fragments or dissociated cells (encompassing the resident stem cells) are embedded in an ECM/basement membrane-mimicking 3D scaffold [such as Matrigel or basement membrane extract (BME)] and cultured in a cocktail of compounds encompassing generic stem cell regulators as well as factors operational in the stem cell niche of the specific tissue. The core of this blend is formed by EGF, Noggin and WNT activators. EGF is a potent mitogen that stimulates epithelial stem cell proliferation while Noggin acts as an inhibitor of BMP signaling which blocks stem cell differentiation. The WNT pathway is a well-known regulator of tissue stem cells, which in organoid culture is generally boosted by adding R-spondin 1 (RSPO1), a ligand of the leucine-rich repeat containing $G$ protein-coupled receptor 5 (LGR5) which marks stem cells in multiple tissues, and which amplifies WNT signaling strength $(128,129,131)$. Using this protocol, organoid models have meanwhile been developed from manifold tissues of both mouse and human origin such as stomach (132), liver (133), and endometrium (134, 135). A key asset of tissue stem cell-derived organoids is that they display strong, long-term expandability while robustly retaining their properties and remaining genomically stable $(128,129)$.

PSC-derived organoid models are achieved by mimicking the sequential steps that occur during embryogenesis of the specific tissue or organ. Embryonic stem cells (ESCs) and induced PSCs (iPSCs), either in 2D or 3D format, are treated with activators or inhibitors of specific embryogenic pathways in a consecutive manner. As an example, organoids mimicking the intestine were obtained by driving human PSC aggregates first toward definitive endoderm using activin $\mathrm{A}$, and then toward hindgut endoderm using WNT3A and FGF4. The obtained floating spheroids were then embedded in Matrigel containing RSPO1, EGF, and Noggin to finally generate an intestinal organoid structure (136). Organoid modeling using PSCs is especially valuable for complex organs composed of several different structures or compartments and therefore difficult to sculpt using the tissue stem cells (which, moreover, are not always clearly identified for those organs), such as brain (137), liver (138), and kidney (139).

In general, organoids provide interesting and powerful application potential in both basic and translational research (Table 1). First, they represent a valuable tool to disentangle tissue development including stem cell biology. In addition, organoids can be used to model diseases $(128,129)$. For example, tumor tissue-derived organoids have been established from different sorts of cancer such as colorectal (140), breast (141), gastric (142), bladder (143), and endometrial cancers (135), resulting in large "living" (cryopreserved) organoid biobanks of patient-derived samples. This resource is highly instrumental for drug screening, which can give insight into inter-individual drug responses and may be translated into 
personalized medicine. Furthermore, organoids can be applied for studying infectious diseases. Eye-catching examples are the application of brain organoids to decipher Zika virus infection (144) and the use of blood vessel, kidney and intestinal organoids to probe and unravel the currently raging SARS-CoV2 infestation $(145,146)$. In the field of regenerative medicine, organoids may also prove constructive to restore damaged or diseased tissue. For instance, it has been shown that human colon-derived organoids move to experimentally damaged areas in mouse colon where they implant and form new tissue with self-renewing crypts that are histologically and functionally normal, thereby displaying long-term engraftment (147). As another example, organoids from primary human hepatocytes engraft and proliferate extensively when transplanted in damaged mouse liver (148).

Both organoid model systems, whether tissue stem cell- or PCS-derived, have pros and cons (Table 1). Tissue stem cellderived organoids are important models to study postnatal tissue stem cell biology (phenotype, regulation, function, activation) which is less straightforward in PSC-derived organoid models in which the adult stem cell phenotype is (as yet) not, or not fully, recapitulated, but instead embryonic progenitor cells are (and can be more effectively studied). Tissue stem cell-derived organoids are long-term and exponentially expandable, allowing to multiply minute tissue samples (e.g., human biopsies) for extensive downstream applications. In contrast, PSC-derived organoids represent an end-point situation, not being passageable, although the starting material (PSCs) can be infinitely expanded first, and large numbers of organoids can then be developed. As already mentioned, PSC-derived organoids are more apt to reproduce complex organs, and different tissue cell types are co-formed during the "organoiding", whereas adult stem cell-derived organoids solely reflect the tissue epithelial compartment. On the other hand, the latter reductionist model may be an asset in specific applications (such as simplified high-throughput screenings). Currently, strong efforts are being made to further advance the adult stem cellderived organoid model by co-culturing epithelial (stem) cells with other cells present in the tissue microenvironment such as mesenchymal, endothelial and immune cells (149, 150). PSCderived organoid models, by their very nature, more closely recapitulate the embryogenic path of the organ, thus providing simultaneous development of different intrinsic tissue-specific cell types, and in some cases (as described below for the pituitary) also extrinsic elements, i.e., neighboring structures that in real life co-develop with the tissue. Finally, both tissue stem cell- and PSC-derived organoids are amenable to gene editing (by, for instance, CRISPR/Cas9), although human iPSCs may show resistance to efficient transfection $(151,152)$.

\section{Pituitary Organoids Derived From Pluripotent Stem Cells}

About 10 years ago, pituitary organoid development was achieved starting from PSCs (153). Based on knowledge of pituitary embryogenesis, mouse ESCs, brought in an aggregate formation, were first directed to oral and neural ectoderm in adjacent layers using a chemically defined medium lacking any growth factors. The aggregates started to express the hypothalamic markers Rax and Sox1 in the inner layer. As occurring in vivo where an intimate, contact-dependent interplay is needed between oral and neural (prospective hypothalamus) ectoderm for pituitary embryogenesis, coexistence of both layers in the 3D ESC configuration was essential to eventually result in the formation of a RP-like structure. This process presented as a morphological invagination and expression of the early pituitary transcription factors PITX1 and LHX3 at the border of both layers upon SHH activation, thereby repeating what is occurring in vivo. Further development toward different pituitary cell lineages was then reached also based on knowledge of mouse pituitary embryogenesis. Corticotropes (visualized by Tbx19 and ACTH expression) were obtained by NOTCH inhibition using DAPT. Driving cells into the somatotrope and lactotrope fate was achieved following WNT pathway stimulation and subsequent exposure to glucocorticoids (for somatotropes) or estradiol (for lactotropes). Functionality was shown for corticotropes which were most efficiently derived (approximately 35\% of the nonneural cells within the ESC-derived structure, meaning 3\% of the total cell number). The differentiated ESC-derived aggregates responded in vitro to the hypothalamic releasing hormone $\mathrm{CRH}$ by increased ACTH release, and rescued in vivo ACTH levels and mouse lethality when subrenally transplanted into hypophysectomized mice (153). A few years later, this tour de force was repeated with human ESCs (154). Hormone-producing cells were generated with corticotropes developing spontaneously (approximately $12 \%$ of the $\mathrm{PITX}^{+}$non-neural cells), somatotropes (and to a lesser extent lactotropes and thyrotropes) appearing after glucocorticoid exposure, and LHand FSH-expressing gonadotropes arising following $\mathrm{NOTCH}$ inhibition. Thus, specific differentiation was found to be different in mouse and human cell cultures (see e.g., the effect of NOTCH inhibition), highlighting important caveats when translating mouse developmental principles to humans. Cells responded to hypothalamic releasing hormones and increased human ACTH expression was observed when aggregate structures were grafted subrenally in hypophysectomized mice (154).

A few years earlier, pituitary hormonal cells were also generated from human ESCs as well as their somatic cellderived counterparts (iPSCs), although in a 2D format (155). Here as well, $\mathrm{SHH}$ signaling was crucial for pituitary specification. $\mathrm{ACTH}^{+}, \mathrm{GH}^{+}$and $\mathrm{FSH}^{+}$hormonal cell types could be developed, with induction of corticotropes again found most efficient. NOTCH inhibition was necessary to increase the development of PIT1- and GATA2-expressing (gonadotrope) lineages. After subcutaneous grafting in vivo in immunodeficient mice, the differentiated cells showed long-term survival and production of human ACTH and GH. In a further refinement, dorsal-ventral patterning (as occurring in pituitary development in vivo) was imposed on the pituitary-directed human PSCs in vitro (156). Treatment with high BMP2 concentration resulted in upregulation of $F S H B$ and $L H B$ 
expression and the detection of $\mathrm{FSH}^{+}$cells (being ventral cell types in embryonic development), whereas high FGF8 exposure yielded increased POMC expression and $\mathrm{POMC}^{+}$cells (dorsal cell type in development), both findings in accordance with knowledge on mouse pituitary embryogenesis in which an opposing BMP2-FGF8 signaling gradient determines dorsalventral patterning and regional cell type specification (157). Intermediate concentrations of both factors resulted in an increase in cells expressing $G H, P R L$, and TSHB as well as of $\mathrm{GH}^{+}$ cells, which are in vivo also found in the transitional zone during development (158). Subcutaneous injection of the differentiated cells (embedded in Matrigel) in hypophysectomized mice showed functional somatotrope and corticotrope cells producing (human) GH and ACTH, respectively (156).

Some recent studies further built on the 3D pituitarydeveloping, human ESC-based organoid model of Ozone et al (154). After transposing the technique to human iPSCs, further endocrine maturation was achieved through creating "hypothalamic-pituitary units" by refining the culture method, but especially by prolonging the culture period (up to 500 days) allowing the hypothalamic neurons to further mature, which concurrently resulted in more progressed development of the pituitary corticotropes (159). Indeed, the resultant units were found to yield better differentiation of $\mathrm{ACTH}^{+}$cells with higher ACTH secretion ability (paralleling levels in adult mice), and were found functional, showing, for instance, physiological responses to hypoglycemic stress in releasing $\mathrm{CRH}$ and ACTH. One caveat, as reported, is that prominent results were only obtained with one iPSC line while three lines were tested showing wide variation in hypothalamus-pituitary induction efficiency (159). Interestingly, the pituitary-developing organoid model was also applied to study pathogenetic mechanisms underlying congenital pituitary hypoplasia $(\mathrm{CPH})$, caused by mutations in orthodenticle homeobox 2 (OTX2), known to be important in the development of forebrain, eye and pituitary (160). OTX2-mutant $\mathrm{CPH}$ patient-derived iPSCs were subjected to the pituitarydeveloping organoid protocol which revealed weakened LHX3 expression, associated with increased apoptosis of the pituitary progenitor cells and impaired differentiation into AP. It was found that OTX2, expressed in the hypothalamic part of the 3D in vitro aggregate, regulates LHX3 expression in the oral ectoderm part via hypothalamic FGF10 expression, eventually essential for progenitor cell maintenance (160). The phenotype was rescued by correcting the mutation, whereas introducing the mutation in control iPSCs resulted in a similar apoptotic picture. Finally, Kanie et al (161). produced iPSCs from an anti-PIT1 syndrome (hypopituitarism) patient and control person which were subjected to the pituitary development protocol (161). Expression of LHX3 was observed after 40 days in culture and of GH, PIT1 and ACTH in some cells after 100 days. PIT1 was found to undergo antigenic processing and presentation; however, no difference was observed between patient and control model system. Together, these studies provide the first human pituitary organoid disease models, nicely illustrating the power and future direction in unraveling (genetic) human pituitary disease by using iPSC-derived organoid model systems.
Taken together, these novel PSC-derived research models provide important tools to study pituitary development which can especially advance our knowledge on human pituitary biology and embryogenesis (at present only concluded from snapshot or longitudinal imaging analyses of embryos or patients with aberrant pituitary development), and/or to generate pituitary endocrine cells for transplantation purposes, since PSCs are amenable to substantial expansion, and large numbers of pituitary endocrine cells can theoretically be generated (Table 1).

\section{Organoids Derived From Pituitary Stem Cells}

Very recently, organoids were established from pituitary stem cells (162). Thorough evaluation of the typical organoid growth factors (see above) and of multiple pituitary embryogenesisrelated signaling molecules such as FGF8, FGF10, and SHH led to the definition of an optimized medium in which organoids could be developed from (mouse) adult AP. The organoids originate from the $\mathrm{SOX}_{2}{ }^{+}$pituitary stem cells as shown by utilizing FACS-sorted SOX2 $2^{\mathrm{eGFP}+}$ cells [from the SOX2 reporter mouse model Sox $\left.2^{\mathrm{eGFP} /+}(163)\right]$, whereas organoids do not form in cultures of the SOX $2^{\text {eGFPneg }}$ cell fraction. The obtained organoids represent the stem cell compartment, as they are completely composed of cells expressing pituitary stem cell markers (such as SOX2 and E-cadherin). After passaging (i.e., breaking the organoids up into fragments which are reseeded in culture, thereby expanding them), the organoids retain this stemness phenotype. Upon transplanting the organoids under the mouse kidney capsule, they engraft and differentiate toward endocrine lineages, albeit at a modest extent (162). To study pituitary stem cell biology and activation after injury, the designed organoid method was applied to the GHCre/ iDTR damage-and-regeneration mouse model [as described above (19)]. The efficiency of pituitary organoid formation was found to be higher when starting from the damaged (GHCre/ iDTR) than the control, undamaged (-/iDTR) pituitary, in agreement with the activated state of the pituitary stem cells after the inflicted injury (162). Increase in organoid formation efficiency was also observed when starting from the neonatal gland (162), again recapitulating the boosted activation status of the stem cell compartment (see above). RNA-seq analysis of the organoids revealed novel pituitary stem cell labels (such as Krt8 and $K r t 18$ ) and damage-upregulated stem cell markers [such as Prrx1/2; see also (164)] which were all confirmed in vivo, illustrating the high potential of this new organoid model as pituitary stem cell biology research tool with reliable in vivo correlate and translatability (162). The model system can be applied to unravel pituitary stem cell biology and activation, or inhibition, during the several conditions of pituitary remodeling as reported above. Moreover, this particular organoid technology can also be used to study pituitary diseases, in particular tumors from which organoids could be developed, and utilized to explore tumorigenic mechanisms and impact of existing medicines, or new pipeline drugs.

Taken together, pituitary organoid models have been developed from PSCs and pituitary stem cells. Both organoid 
types represent interesting, complementary tools to study pituitary biology, each with own advantages and specific applications (Table 1). The PSC-derived model is most apt to study pituitary embryogenesis, moreover enabling the concomitant development of non-epithelial tissue cell types and of the neighoring hypothalamus. In addition, the model can be started from human PSCs, thereby providing a human in vitro pituitary model. The pituitary stem cell-derived organoid model is most suitable to study postnatal pituitary stem cell biology including in-depth characterization of phenotype and of regulatory and activating molecular networks. However, obtaining human normal pituitary tissue (e.g., from autopsy) is very hard to achieve. In contrast, human pituitary tumor samples can be readily obtained from surgery to be turned into tumor organoid models, while the PSC-derived technique is more apt to develop genetic disease models (as illustrated above). At present, the PSC-derived organoid model shows more efficient generation of hormone-producing cells, making it (currently) more apt for unraveling endocrine lineage development and maturation, and for potential regenerative purposes. Technically, setting up pituitary stem cell-derived organoids is less laborintensive and achieved in a short period of time (within 10 days), whereas the PSC-derived model is more hands-on and takes a longer time to develop and mature (from 1 month to 500 days). Moreover, results should be confirmed in several different iPSC lines which are known to be considerably heterogenous in genomic make-up and biological behavior [see (159)].

\section{CONCLUSION}

Plastic adaptation of its cell landscape to changing situations in life is an important property of the pituitary gland. Although these changes in cell constitution and hormonal output are

\section{REFERENCES}

1. Melmed S. The pituitary. 3rd ed. Cambridge: Elsevier/Academic Press (2011).

2. Vankelecom H. "Pituitary stem cells: Quest for hidden functions. In: Research and Perspectives in Endocrine Interactions. Cham, Switzerland: Springer Verlag (2016). p. 81-101. doi: 10.1007/978-3-319-41603-8_7

3. Chen J, Hersmus N, Van Duppen V, Caesens P, Denef C, Vankelecom H. The adult pituitary contains a cell population displaying stem/progenitor cell and early-embryonic characteristics. Endocrinology (2005) 146:3985-98. doi: 10.1210/en.2005-0185

4. Chen J, Gremeaux L, Fu Q, Liekens D, Van Laere S, Vankelecom H. Pituitary progenitor cells tracked down by side population dissection. Stem Cells (2009) 27:1182-95. doi: 10.1002/stem.51

5. Fauquier T, Rizzoti K, Dattani M, Lovell-Badge R, Robinson ICAF. SOX2expressing progenitor cells generate all of the major cell types in the adult mouse pituitary gland. Proc Natl Acad Sci (2008) 105:2907-12. doi: 10.1073/ pnas.0707886105

6. Rizzoti K, Akiyama H, Lovell-Badge R. Mobilized adult pituitary stem cells contribute to endocrine regeneration in response to physiological demand. Cell Stem Cell (2013) 13:419-32. doi: 10.1016/j.stem.2013.07.006

7. Andoniadou CL, Matsushima D, Mousavy Gharavy SN, Signore M, Mackintosh AI, Schaeffer M, et al. Sox2+ stem/progenitor cells in the adult mouse pituitary support organ homeostasis and have tumor-inducing potential. Cell Stem Cell (2013) 13:433-45. doi: 10.1016/j.stem.2013.07.004 known to happen, not much is understood yet on how they are brought about. Here, we looked at this question focusing on the stem cell position in this dynamic play. Although discovered more than a decade ago, many key questions regarding their regulation and biological function and significance remain today. Overall, their contribution to the dynamic cell adaptations as observed in the pituitary remains largely unresolved. With the emergence of new technologies including single-cell transcriptomics and pituitary organoid culturing, several of these questions can be tackled in the near future.

\section{AUTHOR CONTRIBUTIONS}

EL collected all the information and wrote the manuscript. AV provided input on the aging pituitary. HV co-wrote, critically revised, and finalized the manuscript. All authors contributed to the article and approved the submitted version.

\section{FUNDING}

This work was supported by grants from the KU Leuven Research Fund and the Fund for Scientific Research (FWO) - Flanders (Belgium). EL and AV are supported by a PhD Fellowship from the FWO (11A3320N and $1141717 \mathrm{~N}$, respectivey).

\section{ACKNOWLEDGMENTS}

The authors thank the funding agencies as mentioned above for making their research possible.

8. Vankelecom H. Stem cells in the postnatal pituitary? Neuroendocrinology (2007) 85:110-30. doi: 10.1159/000100278

9. Styne DM. The regulation of pubertal growth. In: Hormone Research. Basel, Switzerland: Karger Publishers (2003). p. 22-6. doi: 10.1159/00007 1222

10. Hodson DJ, Schaeffer M, Romanò N, Fontanaud P, Lafont C, Birkenstock J, et al. Existence of long-lasting experience-dependent plasticity in endocrine cell networks. Nat Commun (2012) 3:605. doi: 10.1038/ncomms1612

11. Guillou A, Romanò N, Steyn F, Abitbol K, Le Tissier P, Bonnefont X, et al. Assessment of lactotroph axis functionality in mice: Longitudinal monitoring of PRL secretion by ultrasensitive-ELISA. Endocrinology (2015) 156:1924-30. doi: 10.1210/en.2014-1571

12. Tissier LR, Hodson DJ, Martin AO, Romanò N, Mollard P. Chapter 6: Plasticity of the prolactin (prl) axis: Mechanisms underlying regulation of output in female mice. Adv Exp Med Biol (2014) 846:139-62. doi: 10.1007/ 978-3-319-12114-7_6

13. Martí O, Armario A. Anterior pituitary response to stress : time-related changes and adaptation. Int J Dev Neurosci (1998) 16:241-60. doi: 10.1016/ S0736-5748(98)00030-6

14. Senovilla L, Núñez L, Villalobos C, García-Sancho J. Rapid changes in anterior pituitary cell phenotypes in male and female mice after acute cold stress. Endocrinology (2008) 149:2159-67. doi: 10.1210/en.2007-1030

15. Sasaki F, Wu P, Rougeau D, Unabia G, Childs GV, Childs GV. Cytochemical studies of responses of corticotropes and thyrotropes to cold and novel 
environment stress. Endocrinology (1990) 127:285-97. doi: 10.1210/endo127-1-285

16. Gremeaux L, Fu Q, Chen J, Vankelecom H. Activated phenotype of the pituitary stem/progenitor cell compartment during the early-postnatal maturation phase of the gland. Stem Cells Dev (2012) 21:801-13. doi: $10.1089 /$ scd.2011.0496

17. Kominami R, Yasutaka S, Taniguchi Y, Shinohara H. Proliferating cells in the rat anterior pituitary during the postnatal period: Immunoelectron microscopic observations using monoclonal anti-bromodeoxyuridine antibody. Histochem Cell Biol (2003) 120:223-33. doi: 10.1007/s00418003-0565-9

18. Veldhuis JD. Changes in pituitary function with ageing and implications for patient care. Nat Rev Endocrinol (2013) 9:205-15. doi: 10.1038/ nrendo.2013.38

19. Fu Q, Gremeaux L, Luque RM, Liekens D, Chen J, Buch T, et al. The adult pituitary shows stem/progenitor cell activation in response to injury and is capable of regeneration. Endocrinology (2012) 153:3224-35. doi: 10.1210/ en.2012-1152

20. Fu Q, Vankelecom H. Regenerative capacity of the adult pituitary: Multiple mechanisms of lactotrope restoration after transgenic ablation. Stem Cells Dev (2012) 21:3245-57. doi: 10.1089/scd.2012.0290

21. Willems C, Fu Q, Roose H, Mertens F, Cox B, Chen J, et al. Regeneration in the pituitary after cell-ablation injury: time-related aspects and molecular analysis. Endocrinology (2016) 157:705-21. doi: 10.1210/en.2015-1741

22. Willems C, Vankelecom H. Pituitary cell differentiation from stem cells and other cells toward restorative therapy for hypopituitarism. Regener Med (2014) 9:513-34. doi: 10.2217/RME.14.19

23. Japon MA, Rubinstein M, Low MJ. In situ hybridization analysis of anterior pituitary hormone gene expression during fetal mouse development. J Histochem Cytochem (1994) 42:1117-25. doi: 10.1177/42.8.8027530

24. Levy A. Physiological implications of pituitary trophic activity. J Endocrinol (2002) 174:147-55. doi: 10.1677/joe.0.1740147

25. Zhu X, Gleiberman AS, Rosenfeld MG. Molecular physiology of pituitary development: signaling and transcriptional networks. Physiol Rev (2007) 87:933-63. doi: 10.1152/physrev.00006.2006

26. Davis SW, Ellsworth BS, Peréz Millan MI, Gergics P, Schade V, Foyouzi N, et al. Pituitary gland development and disease: from stem cell to hormone production. Curr Top Dev Biol (2013) 106:1-47. doi: 10.1016/B978-0-12416021-7.00001-8

27. Edwards W, Raetzman LT. Complex integration of intrinsic and peripheral signaling is required for pituitary gland development. Biol Reprod (2018) 99:504-13. doi: 10.1093/biolre/ioy081

28. Kelberman D, Rizzoti K, Lovell-Badge R, Robinson ICAF, Dattani MT. Genetic regulation of pituitary gland development in human and mouse. Endocr Rev (2009) 30:790-829. doi: 10.1210/er.2009-0008

29. Ericson J, Norlin S, Jessell T, Edlund T. Integratedand FGF. BMP signaling controls the progression of progenitor cell differentiation and the emergence of pattern in the embryonic anterior pituitary. Development (1998) 125:1005-15.

30. Cox B, Roose H, Vennekens A, Vankelecom H. Pituitary stem cell regulation: Who is pulling the strings? J Endocrinol (2017) 234:135-58. doi: 10.1530/JOE-17-0083

31. Zhu X, Tollkuhn J, Taylor H, Rosenfeld MG. Notch-dependent pituitary SOX2 + stem cells exhibit a timed functional extinction in regulation of the postnatal gland. Stem Cell Rep (2015) 5:1196-209. doi: 10.1016/j.stemcr.2015.11.001

32. Carbajo-Pérez E, Watanabe YG. Cellular proliferation in the anterior pituitary of the rat during the postnatal period. Cell Tissue Res (1990) 261:333-8. doi: 10.1007/BF00318674

33. Nolan LA, Kavanagh E, Lightman SL, Levy A. Anterior pituitary cell population control: Basal cell turnover and the effects of adrenalectomy and dexamethasone treatment. J Neuroendocrinol (1998) 10:207-15. doi: 10.1046/j.1365-2826.1998.00191.x

34. Florio T. Adult pituitary stem cells: From pituitary plasticity to adenoma development. Neuroendocrinology (2011) 94:265-77. doi: 10.1159/000330857

35. Taniguchi Y, Yasutaka S, Kominami R, Shinohara H. Proliferation and differentiation of rat anterior pituitary cells. Anat Embryol (Berl). (2002) 206:1-11. doi: 10.1007/s00429-002-0271-8

36. Taniguchi Y, Yasutaka S, Kominami R, Shinohara H. Proliferation and differentiation of pituitary somatotrophs and mammotrophs during late fetal and postnatal periods. Anat Embryol (Berl). (2001) 204:469-75. doi: 10.1007/ s429-001-8003-x

37. Taniguchi Y, Yasutaka S, Kominami R, Shinohara H. Proliferation and differentiation of thyrotrophs in the pars distalis of the rat pituitary gland during the fetal and postnatal period. Anat Embryol (Berl). (2001) 203:24953. doi: $10.1007 / \mathrm{s} 004290100161$

38. Cocchia D, Miami N. Immunocytochemical localization of the brain-specific S-100 protein in the pituitary gland of adult rat. J Neurocytol (1980) 9:77182. doi: $10.1007 / \mathrm{BF} 01205018$

39. Nakajima T, Yamaguchi H, Takahashi K. S100 protein in folliculostellate cells of the rat pituitary anterior lobe. Brain Res (1980) 191:523-31. doi: 10.1016/0006-8993(80)91300-1

40. Garcia-Lavandeira M, Quereda V, Flores I, Saez C, Diaz-Rodriguez E, Japon MA, et al. A GRFa2/Prop1/Stem (GPS) cell niche in the pituitary. PLoS One (2009) 4:e4815. doi: 10.1371/journal.pone.0004815

41. Davis SW, Keisler JL, Pérez-Millán MI, Schade V, Camper SA. All hormoneproducing cell types of the pituitary intermediate and anterior lobes derive from prop1-expressing progenitors. Endocrinology (2016) 157:1385-96. doi: $10.1210 /$ en.2015-1862

42. Pérez Millán MI, Brinkmeier ML, Mortensen AH, Camper SA. PROP1 triggers epithelial-mesenchymal transition-like process in pituitary stem cells. Elife (2016) 5:e14470. doi: 10.7554/eLife.14470.001

43. Yoshida S, Kato T, Yako H, Susa T, Cai LY, Osuna M, et al. Significant quantitative and qualitative transition in pituitary stem/ progenitor cells occurs during the postnatal development of the rat anterior pituitary. J Neuroendocrinol (2011) 23:933-43. doi: 10.1111/j.1365-2826.2011. 02198.x

44. Krylyshkina O, Chen J, Mebis L, Denef C, Vankelecom H. Nestinimmunoreactive cells in rat pituitary are neither hormonal nor typical folliculo-stellate cells. Endocrinology (2005) 146:2376-87. doi: 10.1210/ en.2004-1209

45. Yoshida S, Kato T, Higuchi M, Yako H, Chen M, Kanno N, et al. Rapid transition of NESTIN-expressing dividing cells from PROP1-positive to PIT1-positive advances prenatal pituitary development. J Neuroendocrinol (2013) 25:779-91. doi: 10.1111/jne.12077

46. Roose H, Cox B, Boretto M, Gysemans C, Vennekens A, Vankelecom H. Major depletion of SOX2+stem cells in the adult pituitary is not restored which does not affect hormonal cell homeostasis and remodelling. Sci Rep (2017) 7:e16940. doi: 10.1038/s41598-017-16796-2

47. Raetzman LT, Ross SA, Cook S, Dunwoodie SL, Camper SA, Thomas PQ. Developmental regulation of Notch signaling genes in the embryonic pituitary: Prop1 deficiency affects Notch2 expression. Dev Biol (2004) 265:329-40. doi: 10.1016/j.ydbio.2003.09.033

48. Chen J, Crabbe A, Van Duppen V, Vankelecom H. The notch signaling system is present in the postnatal pituitary: marked expression and regulatory activity in the newly discovered side population. Mol Endocrinol (2006) 20:3293-307. doi: 10.1210/me.2006-0293

49. Nantie LB, Himes AD, Getz DR, Raetzman LT. Notch signaling in postnatal pituitary expansion: proliferation, progenitors, and cell specification. Mol Endocrinol (2014) 28:731-44. doi: 10.1210/me.2013-1425

50. Edwards W, Nantie LB, Raetzman LT. Identification of a novel progenitor cell marker, grainyhead-like 2 in the developing pituitary. Dev Dyn (2016) 245:1097-106. doi: 10.1002/dvdy.24439

51. Monahan P, Himes AD, Parfieniuk A, Raetzman LT. P21, an important mediator of quiescence during pituitary tumor formation, is dispensable for normal pituitary development during embryogenesis. Mech Dev (2012) 128:640-52. doi: 10.1016/j.mod.2011.11.002

52. Monahan P, Rybak S, Raetzman LT. The notch target gene Hes1 regulates cell cycle inhibitor expression in the developing pituitary. Endocrinology (2009) 150:4386-94. doi: 10.1210/en.2009-0206

53. Whitlock KE, Illing N, Brideau NJ, Smith KM, Twomey S. Development of GnRH cells: Setting the stage for puberty. Mol Cell Endocrinol (2006) 254255:39-50. doi: 10.1016/j.mce.2006.04.038

54. Brook CGD. Mechanism of Puberty. Horm Res Paediatr (1999) 51:52-4. doi: $10.1159 / 000053162$

55. Herbison AE. Control of puberty onset and fertility by gonadotropinreleasing hormone neurons. Nat Rev Endocrinol (2016) 12:452-66. doi: $10.1038 /$ nrendo.2016.70 
56. Sasaki F. Changes with age in the number and size of anterior pituitary cells in female mice from suckling to adulthood. J Endocrinol (1988) 117:5-10. doi: $10.1677 /$ joe. 0.1170005

57. Rose SR, Municchi G, Barnes KM, Kamp GA, Uriarte MM, Ross JL, et al. Spontaneous growth hormone secretion increases during puberty in normal girls and boys. J Clin Endocrinol Metab (1991) 73:428-35. doi: 10.1210/jcem73-2-428

58. Fontaine R, Ager-Wick E, Hodne K, Weltzien FA. Plasticity in medaka gonadotropes via cell proliferation and phenotypic conversion. J Endocrinol (2020) 245:21-37. doi: 10.1530/JOE-19-0405

59. Cushman LJ, Watkins-Chow DE, Brinkmeier ML, Raetzman LT, Radak AL, Lloyd RV, et al. Persistent Prop1 expression delays gonadotrope differentiation and enhances pituitary tumor susceptibility. Hum $\mathrm{Mol}$ Genet (2001) 10:1141-53. doi: 10.1093/hmg/10.11.1141

60. Vesper AH, Raetzman LT, Camper SA. Role of prophet of Pit1 (PROP1) in gonadotrope differentiation and puberty. Endocrinology (2006) 147:1654-63. doi: 10.1210/en.2005-1080

61. Nasonkin IO, Potok MA, Camper SA. Cre-mediated recombination in pituitary somatotropes. Genesis (2009) 47:55-60. doi: 10.1002/dvg.20462

62. Böttner A, Keller E, Kratzsch J, Stobbe H, Weigel JFW, Keller A, et al. PROP1 mutations cause progressive deterioration of anterior pituitary function including adrenal insufficiency: A longitudinal analysis. J Clin Endocrinol Metab (2004) 89:5256-65. doi: 10.1210/jc.2004-0661

63. Carretero J, Rubio M, Blanco E, Burks DJ, Torres LJL, Hernández E, et al. Variations in the cellular proliferation of prolactin cells from late pregnancy to lactation in rats. Ann Anat (2003) 185:97-101. doi: 10.1016/S0940-9602 (03)80068-7

64. Yin P, Arita J. Differential regulation of prolactin release and lactotrope proliferation during pregnancy, lactation and the estrous cycle. Neuroendocrinology (2000) 72:72-9. doi: 10.1159/000054574

65. Stefaneanu L, Kovacs K, Lloyd RV, Scheithauer BW, Young WF, Sano T, et al. Pituitary lactotrophs and somatotrophs in pregnancy: a correlative in situ hybridization and immunocytochemical study. Virchows Arch B Cell Pathol Incl Mol Pathol (1992) 62:291-6. doi: 10.1007/BF02899695

66. Castrique E, Fernandez-Fuente M, Le Tissier P, Herman A, Levy A. Use of a prolactin-Cre/ROSA-YFP transgenic mouse provides no evidence for lactotroph transdifferentiation after weaning, or increase in lactotroph/ somatotroph proportion in lactation. J Endocrinol (2010) 205:49-60. doi: 10.1677/JOE-09-0414

67. Ho Y, Hu P, Peel MT, Chen S, Camara PG, Epstein DJ, et al. Single-cell transcriptomic analysis of adult mouse pituitary reveals sexual dimorphism and physiologic demand-induced cellular plasticity. Protein Cell (2020) 11:565-83. doi: 10.1007/s13238-020-00705-x

68. Liu L, Rando TA. Manifestations and mechanisms of stem cell aging. J Cell Biol (2011) 193:257-66. doi: 10.1083/jcb.201010131

69. Schultz MB, Sinclair DA. When stem cells grow old: Phenotypes and mechanisms of stem cell aging. Dev (2016) 143:3-14. doi: 10.1242/ dev.130633

70. Kirkwood TBL. Understanding the odd science of aging. Cell (2005) 120:437-47. doi: 10.1016/j.cell.2005.01.027

71. Rando TA. Stem cells, ageing and the quest for immortality. Nature (2006) 441:1080-6. doi: 10.1038/nature04958

72. Console GM, Gomez-Dumm CLA, Goya RG. Immunohistochemical and radioimmunological assessment of thyrotrophs in the pituitary of aging rats. Acta Anat (Basel) (1995) 152:28-32. doi: 10.1159/000147680

73. Kurosumi K, Ozawa H, Akiyama K, Senshu T. Immunoelectron microscopic studies of gonadotrophs in the male and female rat anterior pituitaries, with special reference to their changes with aging. Arch Histol Cytol (1991) 54:559-71. doi: 10.1679/aohc.54.559

74. Cónsole GM, Gómez Dumm CLA, Goya RG. Immunohistochemical and radioimmunological study of pituitary gonadotrophs during aging in male rats. Mech Ageing Dev (1994) 73:87-95. doi: 10.1016/0047-6374(94)90058-2

75. Savine R, Sönksen P. Is the somatopause an indication for growth hormone replacement? J Endocrinol Invest (1999) 22:142-9. doi: 10.1159/000023531

76. San Frutos MG, Cacicedo L, Méndez CF, Vicent D, González M, SánchezFranco F. Pituitary alterations involved in the decline of growth hormone gene expression in the pituitary of aging rats. J Gerontol - Ser A Biol Sci Med Sci (2007) 62:585-97. doi: 10.1093/gerona/62.6.585
77. Kuwahara S, Kesuma Sari D, Tsukamoto Y, Tanaka S, Sasaki F. Age-related changes in growth hormone $(\mathrm{GH})$-releasing hormone and somatostatin neurons in the hypothalamus and in GH cells in the anterior pituitary of female mice. Brain Res (2004) 1025:113-22. doi: 10.1016/j.brainres.2004.08.012

78. Sano T, Kovacs KT, Scheithauer BW, Yiung WF. Aging and the human pituitary gland. Mayo Clin Proc (1993) 68:971-7. doi: 10.1016/S0025-6196 (12)62269-1

79. Broglio F, Benso A, Castiglioni C, Gottero C, Prodam F, Destefanis S, et al. The endocrine response to ghrelin as a function of gender in humans in young and elderly subjects. J Clin Endocrinol Metab (2003) 88:1537-42. doi: 10.1210/jc.2002-021504

80. Garcia J, Merriam G, Kargi A. "Growth Hormone in Aging”, in: Endotext (2019). Available at: https://www.ncbi.nlm.nih.gov/books/NBK279163/ (Accessed August 26, 2020).

81. Cónsole GM, Jurado SB, Riccillo FL, Gómez Dumm CLA. Immunohistochemical and ultrastructural study of pituitary folliculostellate cells during aging in rats. Cells Tissues Organs (2000) 167:25-32. doi: 10.1159/000016763

82. Pavlović M, Jovanović I, Ugrenović S, Vasović L, Krstić M, Bakić M, et al. Morphometric analysis of the human anterior pituitary's folliculostellate cells during the aging process. Ann Anat (2013) 195:231-7. doi: 10.1016/ j.aanat.2012.11.002

83. Armario A, Lopez-Calderon A, Jolin T, Balasch J. Response of anterior pituitary hormones to chronic stress. The specificity of adaptation. Neurosci Biobehav Rev (1986) 10:245-50. doi: 10.1016/0149-7634(86)90011-4

84. Wu P, Childs GV. Changes in rat pituitary POMC mRNA after exposure to cold or a novel environment, detected by in situ hybridization. J Histochem Cytochem (1991) 39:843-52. doi: 10.1177/39.6.1851778

85. Sari DK, Kuwahara S, Furuya M, Tsukamoto Y, Hori H, Kunugita N, et al. Hypothalamo-pituitary-adrenal gland axis in mice inhaling toluene prior to low-level long-term exposure to formaldehyde. J Vet Med Sci (2005) 67:3039. doi: 10.1292/jvms.67.303

86. Jasnic N, Korac A, Velickovic K, Golic I, Djurasevic S, Djordjevic I, et al. The effect of acute heat exposure on rat pituitary corticotroph activation: The role of vasopressin. Folia Histochem Cytobiol (2010) 48:507-12. doi: 10.2478/ v10042-010-0071-6

87. Trifunović S, Lakić I, Vujović P, Jevdjović T, Šošić-Jurjević B, Milošević V, et al. Morphofunctional parameters of rat somatotrophes after acute and repeated immobilization or restraint stress. Acta Histochem (2019) 121:2934. doi: 10.1016/j.acthis.2018.10.003

88. Theogaraj E, John CD, Christian HC, Morris JF, Smith SF, Buckingham JC. Perinatal glucocorticoid treatment produces molecular, functional, and morphological changes in the anterior pituitary gland of the adult male rat. Endocrinology (2005) 146:4804-13. doi: 10.1210/en.2005-0500

89. Nolan LA, Levy A. A population of non-luteinising hormone/nonadrenocorticotrophic hormone-positive cells in the male rat anterior pituitary responds mitotically to both gonadectomy and adrenalectomy. J Neuroendocrinol (2006) 18:655-61. doi: 10.1111/j.1365-2826.2006.01459.x

90. Langlais D, Couture C, Kmita M, Drouin J. Adult pituitary cell maintenance: Lineage-specific contribution of self-duplication. Mol Endocrinol (2013) 27:1103-12. doi: 10.1210/me.2012-1407

91. Melmed S. Pituitary-tumor endocrinopathies. N Engl J Med (2020) 382:93750. doi: 10.1056/NEJMra1810772

92. Mertens F, Gremeaux L, Chen J, Fu Q, Willems C, Roose H, et al. Pituitary tumors contain a side population with tumor stem cell-associated characteristics. Endocr Relat Cancer (2015) 22:481-504. doi: 10.1530/ERC-140546

93. Vankelecom $\mathrm{H}$, Roose $\mathrm{H}$. The stem cell connection of pituitary tumors. Front Endocrinol (Lausanne) (2017) 8:339. doi: 10.3389/fendo.2017.00339

94. Martinez-Barbera JP, Andoniadou CL. Concise review: paracrine role of stem cells in pituitary tumors: a focus on adamantinomatous craniopharyngioma. Stem Cells (2016) 34:268-76. doi: 10.1002/stem.2267

95. Gaston-Massuet C, Andoniadou CL, Signore M, Jayakody SA, Charolidi N, Kyeyune $\mathrm{R}$, et al. Increased Wingless (Wnt) signaling in pituitary progenitor/stem cells gives rise to pituitary tumors in mice and humans. Proc Natl Acad Sci U S A (2011) 108:11482-7. doi: 10.1073/pnas.1101553108

96. Andoniadou CL, Gaston-Massuet C, Reddy R, Schneider RP, Blasco MA, Le Tissier $\mathrm{P}$, et al. Identification of novel pathways involved in the pathogenesis 
of human adamantinomatous craniopharyngioma. Acta Neuropathol (2012) 124:259-71. doi: 10.1007/s00401-012-0957-9

97. Perrone S, Zubeldia-Brenner L, Gazza E, Demarchi G, Baccarini L, Baricalla A, et al. Notch system is differentially expressed and activated in pituitary adenomas of distinct histotype, tumor cell lines and normal pituitaries. Oncotarget (2017) 8:57072-88. doi: 10.18632/oncotarget.19046

98. Lodge EJ, Santambrogio A, Russell JP, Xekouki P, Jacques TS, Johnson RL, et al. Homeostatic and tumourigenic activity of SOX2+ pituitary stem cells is controlled by the LATS/YAP/TAZ cascade. Elife (2019) 8:e43996. doi: 10.7554/eLife.43996

99. Taniguchi-Ponciano K, Andonegui-Elguera S, Peña-Martínez, Eduardo Silva-Román G, Vela-Patiño S, Gomez-Apo E, et al. Transcriptome and methylome analysis reveals three cellular origins of pituitary tumors. Sci Rep (2020) 10:19373. doi: 10.1038/s41598-020-76555-8

100. Schneider HJ, Aimaretti G, Kreitschmann-Andermahr I, Stalla G-K, Ghigo E. Hypopituitarism. Lancet (2007) 369:1461-70. doi: 10.1016/S0140-6736 (07)60673-4

101. Saeger W, Warnecke H. Ultrastructural examination of the regeneration of the rat adenohypophysis after partial hypophysectomy. Virchows Arch A Pathol Anat Histol (1980) 387:279-88. doi: 10.1007/BF00454831

102. Zhao P, Hoffman EP. Embryonic myogenesis pathways in muscle regeneration. Dev Dyn (2004) 229:380-92. doi: 10.1002/dvdy.10457

103. Borrelli E, Heyman R, Hsi M, Evans RM. Targeting of an inducible toxic phenotype in animal cells. Proc Natl Acad Sci U S A (1988) 85:7572-6. doi: 10.1073 /pnas.85.20.7572

104. Tanriverdi F, Schneider HJ, Aimaretti G, Masel BE, Casanueva FF, Kelestimur F. Pituitary dysfunction after traumatic brain injury: A clinical and pathophysiological approach. Endocr Rev (2015) 36:305-42. doi: 10.1210/er.2014-1065

105. Vennekens A, Vankelecom $\mathrm{H}$. Traumatic brain injury and resultant pituitary dysfunction: insights from experimental animal models. Pituitary (2019) 22:212-9. doi: 10.1007/s11102-019-00961-z

106. Aimaretti G, Ambrosio MR, Di Somma C, Gasperi M, Cannavò S, Scaroni C, et al. Residual pituitary function after brain injury-induced hypopituitarism: A prospective 12-month study. J Clin Endocrinol Metab (2005) 90:6085-92. doi: 10.1210/jc.2005-0504

107. Tanriverdi F, Ulutabanca H, Unluhizarci K, Selcuklu A, Casanueva FF, Kelestimur F. Three years prospective investigation of anterior pituitary function after traumatic brain injury: A pilot study. Clin Endocrinol (Oxf) (2008) 68:573-9. doi: 10.1111/j.1365-2265.2007.03070.x

108. Karaca Z, Tanriverdi F, Dagli AT, Selcuklu A, Casanueva FF, Unluhizarci K, et al. Three years prospective investigation of pituitary functions following subarachnoid haemorrhage. Pituitary (2013) 16:76-82. doi: 10.1007/s11102012-0377-9

109. Yoshimura F, Harumiya K, Ishikawa H, Otsuka Y. Differentiation of isolated chromophobes into acidophils or basophils when transplanted into the hypophysiotrophic area of hypothalamus. Endocrinol Jpn (1969) 16:53140. doi: 10.1507/endocrj1954.16.531

110. Landolt AM. Regeneration of the human pituitary. J Neurosurg (1973) 39:3541. doi: 10.3171/jns.1973.39.1.0035

111. Ooi GT, Tawadros N, Escalona RM. Pituitary cell lines and their endocrine applications. Mol Cell Endocrinol (2004) 228:1-21. doi: 10.1016/ j.mce.2004.07.018

112. Bjøro T, Sand O, Østberg BC, Gordeladze JO, Torjesen P, Gautvik KM, et al. The mechanisms by which vasoactive intestinal peptide (VIP) and thyrotropin releasing hormone (TRH) stimulate prolactin release from pituitary cells. Biosci Rep (1990) 10:189-99. doi: 10.1007/BF01116578

113. Danila DC, Zhang X, Zhou Y, Dickersin GR, Fletcher JA, Hedley-Whyte ET, et al. A human pituitary tumor-derived folliculostellate cell Line 1. J Clin Endocrinol Metab (2000) 85:1180-7. doi: 10.1210/jcem.85.3.6424

114. Castro CP, Nagashima AC, Pereda MP, Goldberg V, Chervin A, Largen P, et al. The gp130 cytokines interleukin-11 and ciliary neurotropic factor regulate through specific receptors the function and growth of lactosomatotropic and folliculostellate pituitary cell lines. Endocrinology (2000) 141:1746-53. doi: 10.1210/endo.141.5.7442

115. Lohrer P, Gloddek J, Nagashima AC, Korali Z, Hopfner U, Pereda MP, et al. Lipopolysaccharide directly stimulates the intrapituitary interleukin-6 production by folliculostellate cells via specific receptors and the $\mathrm{p} 38 \alpha$ mitogen-activated protein kinase/nuclear factor- $\kappa \mathrm{B}$ pathway 1 . Endocrinology (2000) 141:4457-65. doi: 10.1210/endo.141.12.7811

116. Renner U, Gloddek J, Pereda MP, Arzt E, Stalla GK. Regulation and role of intrapituitary IL-6 production by folliculostellate cells. Domest Anim Endocrinol (1998) 15:353-62. doi: 10.1016/S0739-7240(98)00027-7

117. Gomm JJ, Ray KP, Wallis M. Purification of ovine somatotrophs using a combination of density gradient centrifugation and short-term culture. J Endocrinol (1987) 115:395-403. doi: 10.1677/joe.0.1150395

118. Velkeniers B, Smets G, Baldys A, Buydens P, Finné E, Vanhaelst L. Linear Percoll gradient centrifugation of rat anterior pituitary cells. A simple method for prolactin cell enrichment. J Endocrinol Invest (1987) 10:24753. doi: $10.1007 / \mathrm{BF} 03348123$

119. Childs GV, Lloyd JM, Rougeau D, Unabia G. Enrichment of corticotropes by counterflow centrifugation. Endocrinology (1988) 123:2885-95. doi: 10.1210/ endo-123-6-2885

120. Binoux M, Hossenlopp P, Gourmelen M, Girard F. Biosynthesis and hormonal regulation of IGF (insulin-like growth factors, or somatomedins). Experimental and clinical studies. Ann Endocrinol (1980) 41:487-94.

121. Sato SM, Mains RE. Regulation of adrenocorticotropin/endorphin-related peptide secretion in neonatal rat pituitary cultures. Endocrinology (1986) 119:793-801. doi: 10.1210/endo-119-2-793

122. Watanabe YG, Matsumura H, Daikoku S. Electron microscopic study of rat pituitary primordium in organ culture. $Z$ für Zellforsch und Mikroskopische Anat (1973) 146:453-61. doi: 10.1007/BF02347175

123. Van Bael A, Seuntjens E, Proesmans M, Denef C. Presence of gonadotropinreleasing hormone $(\mathrm{GnRH}) \mathrm{mRNA}$ in Rathke's pouch and effect of the GnRHantagonist ORG 30276 on lactotroph development in vitro. J Neuroendocrinol (1998) 10:437-45. doi: 10.1046/j.1365-2826.1998.00205.x

124. Van der Schueren B, Denef C, Cassiman JJ. Ultrastructural and functional characteristics of rat pituitary cell aggregates. Endocrinology (1982) 110:51323. doi: $10.1210 /$ endo-110-2-513

125. Denef C. Paracrinicity: the story of thirty years of cellular pituitary crosstalk. J Neuroendocrinol (2007) 20:1-70. doi: 10.1111/j.1365-2826.2007.01616.x

126. Gritti A, Parati EA, Cova L, Frolichsthal P, Galli R, Wanke E, et al. Multipotential stem cells from the adult mouse brain proliferate and selfrenew in response to basic fibroblast growth factor. J Neurosci (1996) 16:1091-100. doi: 10.1523/JNEUROSCI.16-03-01091.1996

127. Gleiberman AS, Michurina T, Encinas JM, Roig JL, Krasnov P, Balordi F, et al. Genetic approaches identify adult pituitary stem cells. Proc Natl Acad Sci U S A (2008) 105:6332-7. doi: 10.1073/pnas.0801644105

128. Kretzschmar K, Clevers H. Organoids: modeling development and the stem cell niche in a dish. Dev Cell (2016) 38:590-600. doi: 10.1016/j.devcel.2016.08.014

129. Clevers H. Modeling development and disease with organoids. Cell (2016) 165:1586-97. doi: 10.1016/j.cell.2016.05.082

130. Sato T, Vries RG, Snippert HJ, Van De Wetering M, Barker N, Stange DE, et al. Single Lgr5 stem cells build crypt-villus structures in vitro without a mesenchymal niche. Nature (2009) 459:262-5. doi: 10.1038/nature07935

131. Nusse R, Clevers $H$. Wnt/ $\beta$-catenin signaling, disease, and emerging therapeutic modalities. Cell (2017) 169:985-99. doi: 10.1016/ j.cell.2017.05.016

132. Barker N, Huch M, Kujala P, van de Wetering M, Snippert HJ, van Es JH, et al. Lgr5+ve stem cells drive self-renewal in the stomach and build longlived gastric units in vitro. Cell Stem Cell (2010) 6:25-36. doi: 10.1016/ J.STEM.2009.11.013

133. Huch M, Dorrell C, Boj SF, van Es JH, Li VSW, van de Wetering M, et al. In vitro expansion of single Lgr5+ liver stem cells induced by Wnt-driven regeneration. Nature (2013) 494:247-50. doi: 10.1038/nature11826

134. Boretto M, Cox B, Noben M, Hendriks N, Fassbender A, Roose H, et al. Development of organoids from mouse and human endometrium showing endometrial epithelium physiology and long-term expandability. Development (2017) 144:1775-86. doi: 10.1242/dev.148478

135. Boretto M, Maenhoudt N, Luo X, Hennes A, Boeckx B, Bui B, et al. Patientderived organoids from endometrial disease capture clinical heterogeneity and are amenable to drug screening. Nat Cell Biol (2019) 21:1041-51. doi: 10.1038/s41556-019-0360-z

136. Spence JR, Mayhew CN, Rankin SA, Kuhar MF, Vallance JE, Tolle K, et al. Directed differentiation of human pluripotent stem cells into intestinal tissue in vitro. Nature (2011) 470:105-10. doi: 10.1038/nature09691 
137. Lancaster MA, Renner M, Martin CA, Wenzel D, Bicknell LS, Hurles ME, et al. Cerebral organoids model human brain development and microcephaly. Nature (2013) 501:373-9. doi: 10.1038/nature12517

138. Takebe T, Sekine K, Enomura M, Koike H, Kimura M, Ogaeri T, et al. Vascularized and functional human liver from an iPSC-derived organ bud transplant. Nature (2013) 499:481-4. doi: 10.1038/nature12271

139. Xia Y, Nivet E, Sancho-Martinez I, Gallegos T, Suzuki K, Okamura D, et al. Directed differentiation of human pluripotent cells to ureteric bud kidney progenitor-like cells. Nat Cell Biol (2013) 15:1507-15. doi: 10.1038/ncb2872

140. Van De Wetering M, Francies HE, Francis JM, Bounova G, Iorio F, Pronk A, et al. Prospective derivation of a living organoid biobank of colorectal cancer patients. Cell (2015) 161:933-45. doi: 10.1016/j.cell.2015.03.053

141. Sachs N, de Ligt J, Kopper O, Gogola E, Bounova G, Weeber F, et al. A living biobank of breast cancer organoids captures disease heterogeneity. Cell (2018) 172:373-386.e10. doi: 10.1016/j.cell.2017.11.010

142. Yan HHN, Siu HC, Law S, Ho SL, Yue SSK, Tsui WY, et al. A comprehensive human gastric cancer organoid biobank captures tumor subtype heterogeneity and enables therapeutic screening. Cell Stem Cell (2018) 23:882-897.e11. doi: 10.1016/j.stem.2018.09.016

143. Lee SH, Hu W, Matulay JT, Silva MV, Owczarek TB, Kim K, et al. Tumor evolution and drug response in patient-derived organoid models of bladder cancer. Cell (2018) 173:515-28.e17. doi: 10.1016/j.cell.2018.03.017

144. Garcez PP, Loiola EC, Da Costa RM, Higa LM, Trindade P, Delvecchio R, et al. Zika virus: Zika virus impairs growth in human neurospheres and brain organoids. Science (80- ) (2016) 352:816-8. doi: 10.1126/science.aaf6116

145. Monteil V, Kwon H, Prado P, Hagelkrüys A, Wimmer RA, Stahl M, et al. Inhibition of SARS-CoV-2 infections in engineered human tissues using clinical-grade soluble human ACE2. Cell (2020) 181:905-13.e7. doi: 10.1016/ j.cell.2020.04.004

146. Lamers MM, Beumer J, van der Vaart J, Knoops K, Puschhof J, Breugem TI, et al. SARS-CoV-2 productively infects human gut enterocytes. Science (80- ) (2020) 369:50-4. doi: 10.1126/science.abc1669

147. Yui S, Nakamura T, Sato T, Nemoto Y, Mizutani T, Zheng X, et al. Functional engraftment of colon epithelium expanded in vitro from a single adult Lgr5+ stem cell. Nat Med (2012) 18:618-23. doi: 10.1038/ nm.2695

148. Hu H, Gehart H, Artegiani B, LÖpez-Iglesias C, Dekkers F, Basak O, et al. Long-term expansion of functional mouse and human hepatocytes as 3D organoids. Cell (2018) 175:1591-606.e19. doi: 10.1016/j.cell.2018.11.013

149. Seino T, Kawasaki S, Shimokawa M, Tamagawa H, Toshimitsu K, Fujii M, et al. Human pancreatic tumor organoids reveal loss of stem cell niche factor dependence during disease progression. Cell Stem Cell (2018) 22:454-67.e6. doi: 10.1016/j.stem.2017.12.009

150. Viney ME, Bullock AJ, Day MJ, MacNeil S. Co-culture of intestinal epithelial and stromal cells in 3D collagen-based environments. Regener Med (2009) 4:397-406. doi: 10.2217/rme.09.4

151. Schwank G, Koo BK, Sasselli V, Dekkers JF, Heo I, Demircan T, et al. Functional repair of CFTR by CRISPR/Cas9 in intestinal stem cell organoids of cystic fibrosis patients. Cell Stem Cell (2013) 13:653-8. doi: 10.1016/ j.stem.2013.11.002

152. Matano M, Date S, Shimokawa M, Takano A, Fujii M, Ohta Y, et al. Modeling colorectal cancer using CRISPR-Cas9-mediated engineering of human intestinal organoids. Nat Med (2015) 21:256-62. doi: 10.1038/ nm.3802
153. Suga H, Kadoshima T, Minaguchi M, Ohgushi M, Soen M, Nakano T, et al. Self-formation of functional adenohypophysis in three-dimensional culture. Nature (2011) 480:57-62. doi: 10.1038/nature10637

154. Ozone C, Suga H, Eiraku M, Kadoshima T, Yonemura S, Takata N, et al. Functional anterior pituitary generated in self-organizing culture of human embryonic stem cells. Nat Commun (2016) 7:10351. doi: 10.1038/ ncomms 10351

155. Dincer Z, Piao J, Niu L, Ganat Y, Kriks S, Zimmer B, et al. Specification of functional cranial placode derivatives from human pluripotent stem cells. Cell Rep (2013) 5:1387-402. doi: 10.1016/j.celrep.2013.10.048

156. Zimmer B, Piao J, Ramnarine K, Tomishima MJ, Tabar V, Studer L. Derivation of diverse hormone-releasing pituitary cells from human pluripotent stem cells. Stem Cell Rep (2016) 6:858-72. doi: 10.1016/ j.stemcr.2016.05.005

157. Treier M, Gleiberman AS, O’Connell SM, Szeto DP, McMahon JA, McMahon AP, et al. Multistep signaling requirements for pituitary organogenesis in vivo. Genes Dev (1998) 12:1691-704. doi: 10.1101/gad.12.11.1691

158. Kioussi C, Carrière C, Rosenfeld MG. A model for the development of the hypothalamic-pituitary axis: Transcribing the hypophysis. Mech Dev (1999) 81:23-35. doi: 10.1016/S0925-4773(98)00229-9

159. Kasai T, Suga H, Sakakibara M, Ozone C, Matsumoto R, Kano M, et al. Hypothalamic contribution to pituitary functions is recapitulated in vitro using 3D-cultured human iPS cells. Cell Rep (2020) 30:18-24.e5. doi: 10.1016/j.celrep.2019.12.009

160. Matsumoto R, Suga H, Aoi T, Bando H, Fukuoka H, Iguchi G, et al. Congenital pituitary hypoplasia model demonstrates hypothalamic OTX2 regulation of pituitary progenitor cells. J Clin Invest (2019) 130:641-54. doi: 10.1172/JCI127378

161. Kanie K, Bando H, Iguchi G, Muguruma K, Matsumoto R, Hidaka-Takeno $\mathrm{R}$, et al. Pathogenesis of anti-PIT-1 antibody syndrome: PIT-1 presentation by HLA class I on anterior pituitary cells. J Endocr Soc (2019) 3:1969-78. doi: 10.1210/js.2019-00243

162. Cox B, Laporte E, Vennekens A, Kobayashi H, Nys C, Van Zundert I, et al. Organoids from pituitary as novel research model to study pituitary stem cell biology. J Endocrinol (2019) 240:287-308. doi: 10.1530/JOE-18-0462

163. Ellis P, Fagan BM, Magness ST, Hutton S, Taranova O, Hayashi S, et al. SOX2, a persistent marker for multipotential neural stem cells derived from embryonic stem cells, the embryo or the adult. Dev Neurosci (2004) 26:14865. doi: $10.1159 / 000082134$

164. Higuchi M, Yoshida S, Ueharu H, Chen M, Kato T, Kato Y. PRRX1 and PRRX2 distinctively participate in pituitary organogenesis and a cell-supply system. Cell Tissue Res (2014) 357:323-35. doi: 10.1007/s00441-014-1861-5

Conflict of Interest: The authors declare that the research was conducted in the absence of any commercial or financial relationships that could be construed as a potential conflict of interest.

Copyright (C) 2021 Laporte, Vennekens and Vankelecom. This is an open-access article distributed under the terms of the Creative Commons Attribution License (CC BY). The use, distribution or reproduction in other forums is permitted, provided the original author(s) and the copyright owner(s) are credited and that the original publication in this journal is cited, in accordance with accepted academic practice. No use, distribution or reproduction is permitted which does not comply with these terms. 